\title{
Formation and distribution characteristics of Proterozoic-Lower Paleozoic marine giant oil and gas fields worldwide
}

\author{
Xiao-Ping Liu ${ }^{1,2} \cdot$ Zhi-Jun Jin $^{3}$ - Guo-Ping Bai ${ }^{1,2} \cdot$ Ming Guan $^{2} \cdot \mathrm{Jie} \mathrm{Liu}^{2}$ • \\ Qing-Hua Pan $^{2,4} \cdot$ Ting $\mathrm{Li}^{2,5} \cdot$ Yu-Jie Xing ${ }^{2}$
}

Received: 7 April 2016/Published online: 22 April 2017

(c) The Author(s) 2017. This article is an open access publication

\begin{abstract}
There are rich oil and gas resources in marine carbonate strata worldwide. Although most of the oil and gas reserves discovered so far are mainly distributed in Mesozoic, Cenozoic, and upper Paleozoic strata, oil and gas exploration in the Proterozoic-Lower Paleozoic (PLP) strata - the oldest marine strata-has been very limited. To more clearly understand the oil and gas formation conditions and distributions in the PLP marine carbonate strata, we analyzed and characterized the petroleum geological conditions, oil and gas reservoir types, and their distributions in thirteen giant oil and gas fields worldwide. This study reveals the main factors controlling their formation and distribution. Our analyses show that the source rocks for these giant oil and gas fields are mainly shale with a great abundance of type I-II organic matter and a high thermal evolution extent. The reservoirs are mainly gas reservoirs, and the reservoir rocks are dominated by dolomite. The reservoir types are mainly karst and reef-shoal bodies with well-developed dissolved pores and cavities, intercrystalline pores, and fractures. These reservoirs are
\end{abstract}

Xiao-Ping Liu

liuxiaoping@cup.edu.cn

1 State Key Laboratory of Petroleum Resources and Prospecting, Beijing 102249, China

2 College of Geosciences, China University of Petroleum, Beijing 102249, China

3 Petroleum Exploration and Production Research Institute, SINOPEC, Beijing 100083, China

4 Exploration and Development Research Institute, PetroChina Huabei Oilfield Company, Renqiu 062552, Hebei, China

5 Exploration and Development Research Institute, PetroChina Tarim Oilfield Company, Korla 841000, Xinjiang, China

Edited by Jie Hao highly heterogeneous. The burial depth of the reservoirs is highly variable and somewhat negatively correlated to the porosity. The cap rocks are mainly thick evaporites and shales, with the thickness of the cap rocks positively correlated to the oil and gas reserves. The development of high-quality evaporite cap rock is highly favorable for oil and gas preservation. We identified four hydrocarbon generation models, and that the major source rocks have undergone a long period of burial and thermal evolution and are characterized by early and long periods of hydrocarbon generation. These giant oil and gas fields have diverse types of reservoirs and are mainly distributed in paleo-uplifts, slope zones, and platform margin reef-shoal bodies. The main factors that control their formation and distribution were identified, enabling the prediction of new favorable areas for oil and gas exploration.

Keywords Giant oil and gas field - Proterozoic and Lower Paleozoic - Marine carbonate rocks · Petroleum geological conditions $\cdot$ Oil and gas distribution

\section{Introduction}

Oil and gas fields with recoverable reserves of more than $500 \times 10^{6} \mathrm{bbl}$ of oil equivalent are referred to as giant oil and gas field (Halbouty 2003; Bai 2006). According to the IHS Energy Group database, as of 2014, 1087 giant oil and gas fields have been found worldwide, accounting for $72.5 \%$ of the global conventional proven and probable reserves, and $54.5 \%$ of them are located in marine carbonate rocks. Therefore, marine carbonate rocks have considerable oil and gas potential (Jia et al. 2006; Gu et al. 2012; Bai and Xu 2014). Most of the discovered oil and gas reserves in carbonate rocks are mainly distributed in the 
Mesozoic (mostly Jurassic and Cretaceous) strata, followed by the Cenozoic and upper Paleozoic strata, with very few in the Proterozoic-Lower Paleozoic (PLP) strata. Only $2.3 \%$ of the total carbonate oil and gas reserves in the oldest strata have been found, because exploration has been very limited there and thus great potential exists for exploration, particularly in China and the Asia-Pacific hydrocarbon-rich regions ( $\mathrm{Yu}$ et al. 2012; Jin et al. 2013; Bai and Cao 2014). Indeed, oil and gas fields have been found in the PLP marine carbonate strata in dozens of basins worldwide, including thirteen giant oil and gas fields (Fig. 1), namely the Tahe and Tazhong 1 oil and gas fields in the Tarim Basin; the Jingbian gas field in the Ordos Basin; the Anyue gas field in the Sichuan Basin; the Verkhne-Vilyuchanka, Kuyumba, Talakan, YurubchenoTokhomo oil and gas fields in the East Siberian Basin; the Puckett and Gomez gas fields in the Permian Basin; the Niagaran Reef Trend oil and gas field in the Michigan Basin; the Lima-Indiana Trend oil and gas field in the
Indiana-Ohio platform; and the Makarem 1 oil and gas field in the Oman Basin (Fig. 2; Table 1). A clearer understanding of the geologic conditions and distribution characteristics of these giant oil and gas fields would offer valuable insights for further exploration of oil and gas resources in the PLP marine carbonate strata worldwide.

\section{Geological background}

\subsection{Tectonic evolution of the basins}

The basins with giant oil and gas fields found in the PLP strata are based on Precambrian metamorphic rocks or granites with basement faults, and they are characterized by the development of cratonic basins in the Proterozoic or Paleozoic periods. These basins are very large. For example, the East Siberian Basin covers an area of $350 \times 10^{4}$ $\mathrm{km}^{2}$, while the other basins are hundreds of thousands of

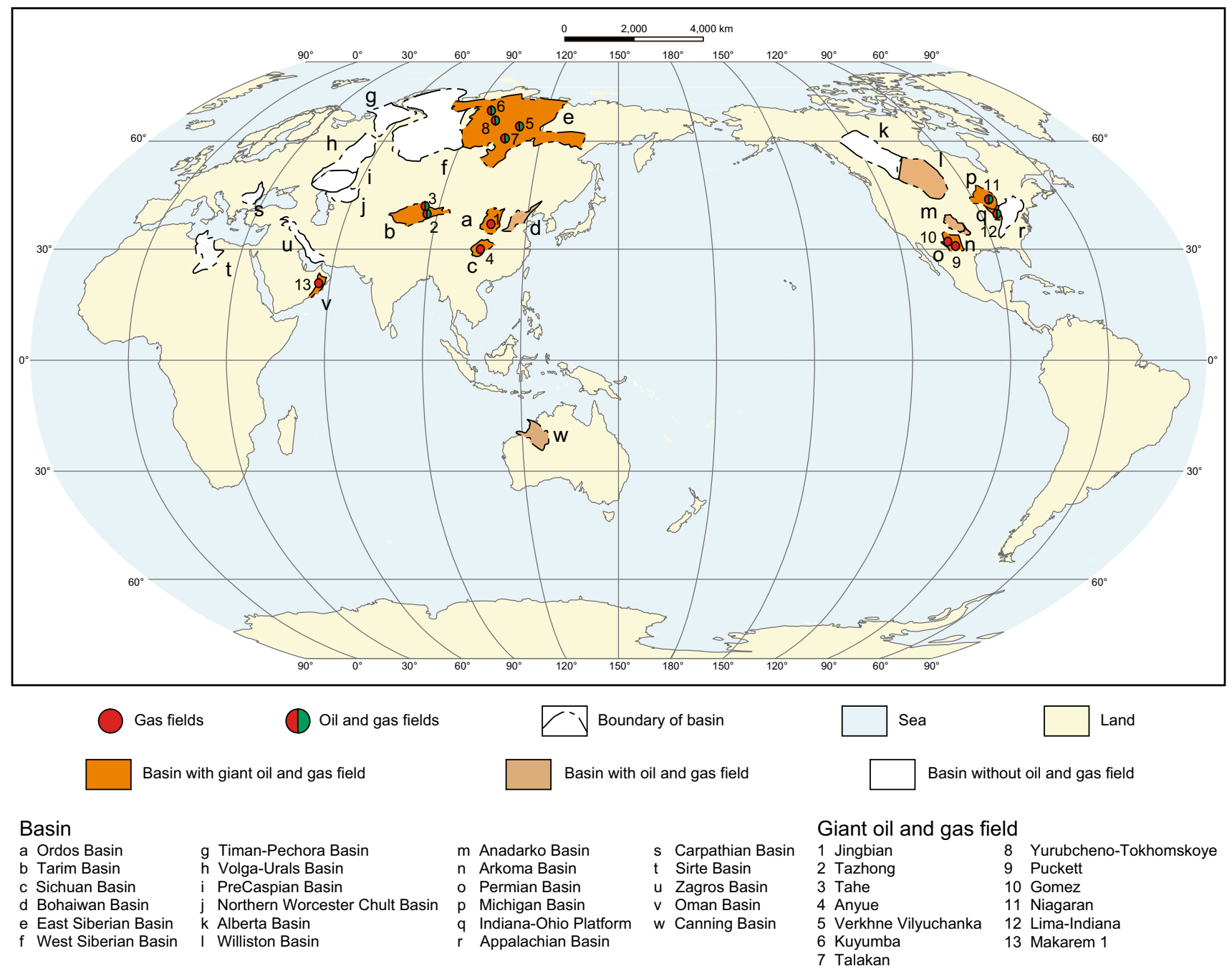

Fig. 1 Location of marine carbonate giant oil and gas fields in the Proterozoic-Lower Paleozoic strata worldwide 


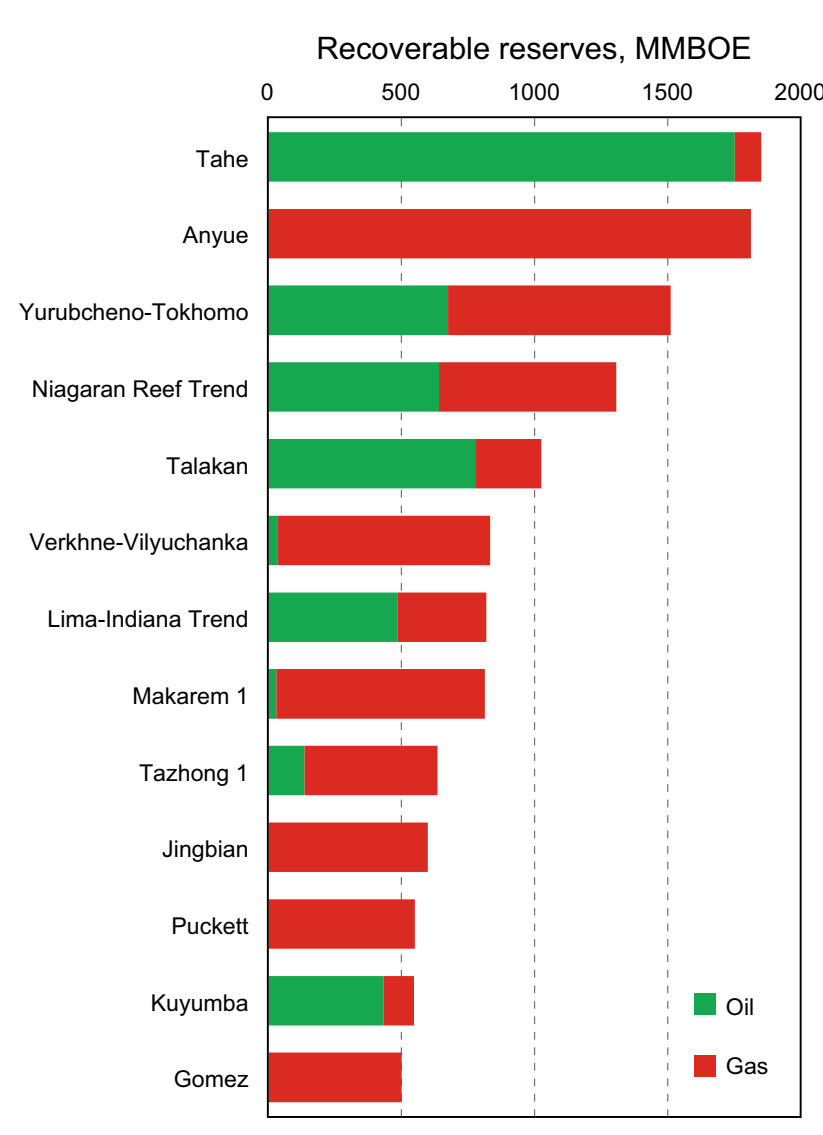

Fig. 2 Recoverable reserves of marine carbonate giant oil and gas fields in the Proterozoic-Lower Paleozoic strata worldwide

square kilometers in size. Except for the Michigan Basin and Indiana-Ohio Platform, which are on stable cratons, other basins are superimposed basins that have undergone multistage structural evolution from stable craton basins in the Proterozoic or Lower Paleozoic. Among them, the Ordos Basin is a Mesozoic and Cenozoic rift basin that evolved from a late Proterozoic to early Paleozoic craton basin; the Tarim Basin, Permian Basin, East Siberian Basin, and Oman Basin are Mesozoic and Cenozoic foreland basins evolved from the Paleozoic craton basins, and the Sichuan Basin was a Late Triassic foreland basin that evolved from a Sinian into a Middle Triassic craton basin, and then finally evolved into an early Jurassic to Cretaceous depression basin.

Each basin has distinct evolutionary characteristics. The Ordos Basin is located in the southwest of the North China platform on an Archaeozoic and early Proterozoic granite and metamorphic basement. It has experienced multiple tectonic evolutions (Liu et al. 2009a; Zhao et al. 2012a). The Tarim Basin on the Tarim platform was developed on a Precambrian crystalline metamorphic basement. It is a multicycle superimposed basin, formed from a stably developed Paleozoic marine cratonic basin and MesozoicCenozoic foreland basin by thrust tectonics and has experienced multiphase tectonic movements and superimposed sedimentation (Jia and Wei 2002; Xu et al. 2004; He et al. 2005; Zhang et al. 2007a; Pang et al. 2012). The Sichuan Basin is located in the northwest of the Yangtze plate. It was superimposed on a Proterozoic crystalline basement with a Sinian to Middle Triassic cratonic basin, a Triassic foreland basin, and an early Jurassic to Middle Cretaceous depression basin (Liu et al. 2011; He et al. 2011a). The Permian Basin in the southern margin of the North American platform is a Paleozoic cratonic basin developed on a Precambrian crystalline basement. In the early Paleozoic period, it was a carbonate shelf deposit in a shallow sea, gently inclining southeast and having multistage tectonic evolutions. This basin mainly consists of the Central Basin platform, the Delaware Basin, the Midland Basin, and the Val Verde Basin (McKee et al. 1967; Hills 1984; Yang and Dorobek 1995). The Michigan Basin is located in the east of the North American platform. It is a relatively stable intracratonic basin deposited on a Precambrian crystalline basement (Charpentier 1987; Catacosinos et al. 1990). The East Siberian Basin was developed on the Siberian platform on an ArcheanProterozoic metamorphic basement. It has experienced multiphase tectonic movements and formed the current tectonic patterns of alternative depressions and uplifts, and Mesozoic-Cenozoic foreland basins have developed in the margin of the basin (Kheraskova et al. 2009; Nikishin et al. 2010; Zhu et al. 2012; Du et al. 2013; Frolov et al. 2015). The Oman Basin is located in the southeast part of the Arabian Plate. It is also a large superimposed basin and evolved from a Precambrian interior cratonic rift into a Paleozoic inland depressed basin, and subsequently experienced multistage tectonic evolutions (Loosveld et al. 1996; Filbrandt et al. 2006; Zhu et al. 2014).

\subsection{Sedimentary characteristics}

The PLP strata in these basins mainly consist of marine carbonate sediment (Fig. 3). In the early Paleozoic, the Ordos Basin was a shallow epicontinental sea and later evolved from a carbonate gentle slope in the epicontinental sea into a carbonate platform and then into a weathered and denuded paleo-continental deposit (Wei et al. 1997; Li 2009). The Tarim Basin comprised marine strata from the Sinian to early Permian periods; its Lower part was clastic rock intercalated with carbonate rock. The central part was carbonate rock, and the upper part was clastic rock intercalated with carbonate rocks, which were mostly Cambrian and Ordovician (Jia and Wei 2002; Xiao et al. 2011). The Sichuan Basin sediments were marine craton carbonate with a clastic sedimentary stage in the Sinian to Middle Triassic periods (He et al. 2011a). The Permian Basin has been subject to Paleozoic marine and Mesozoic-Cenozoic 


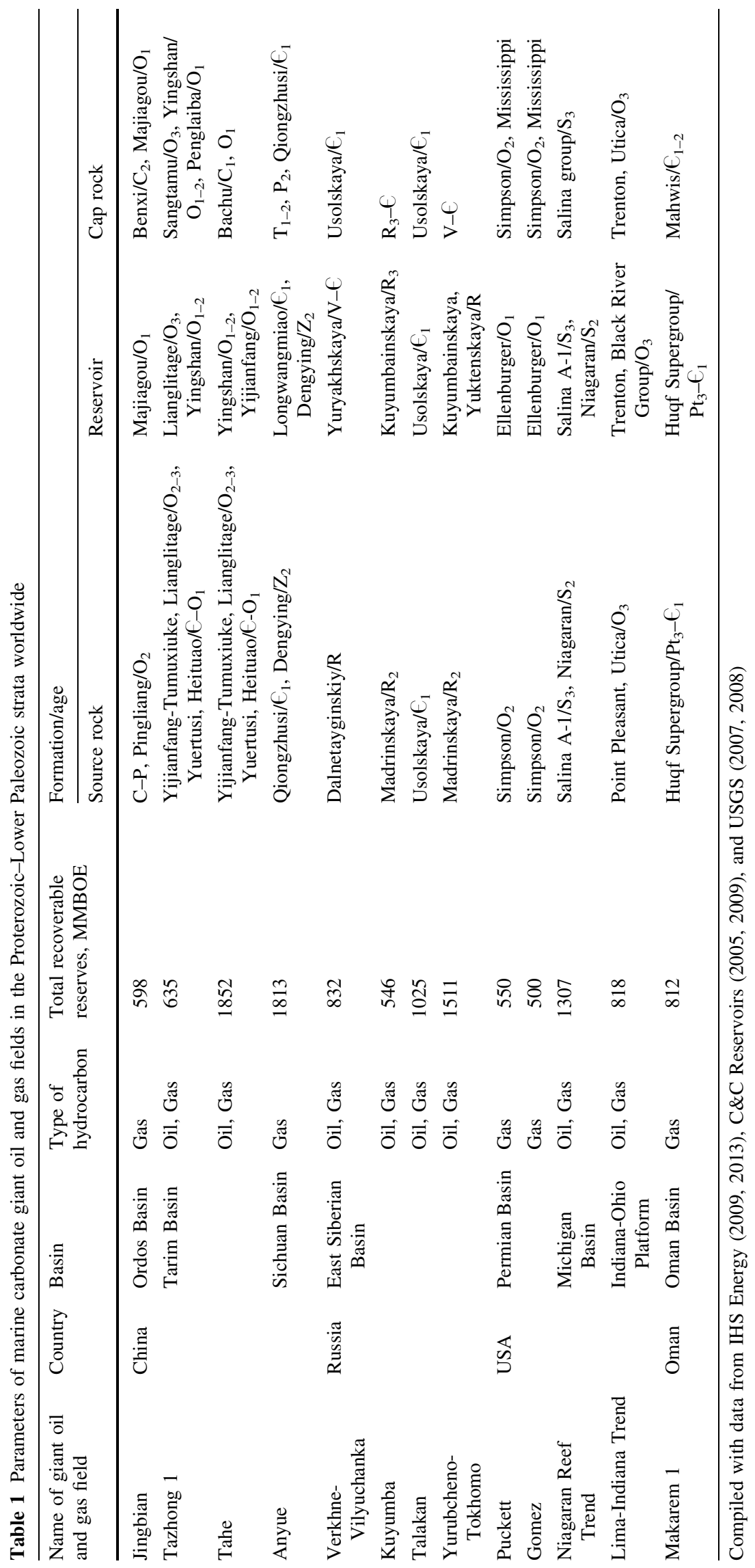




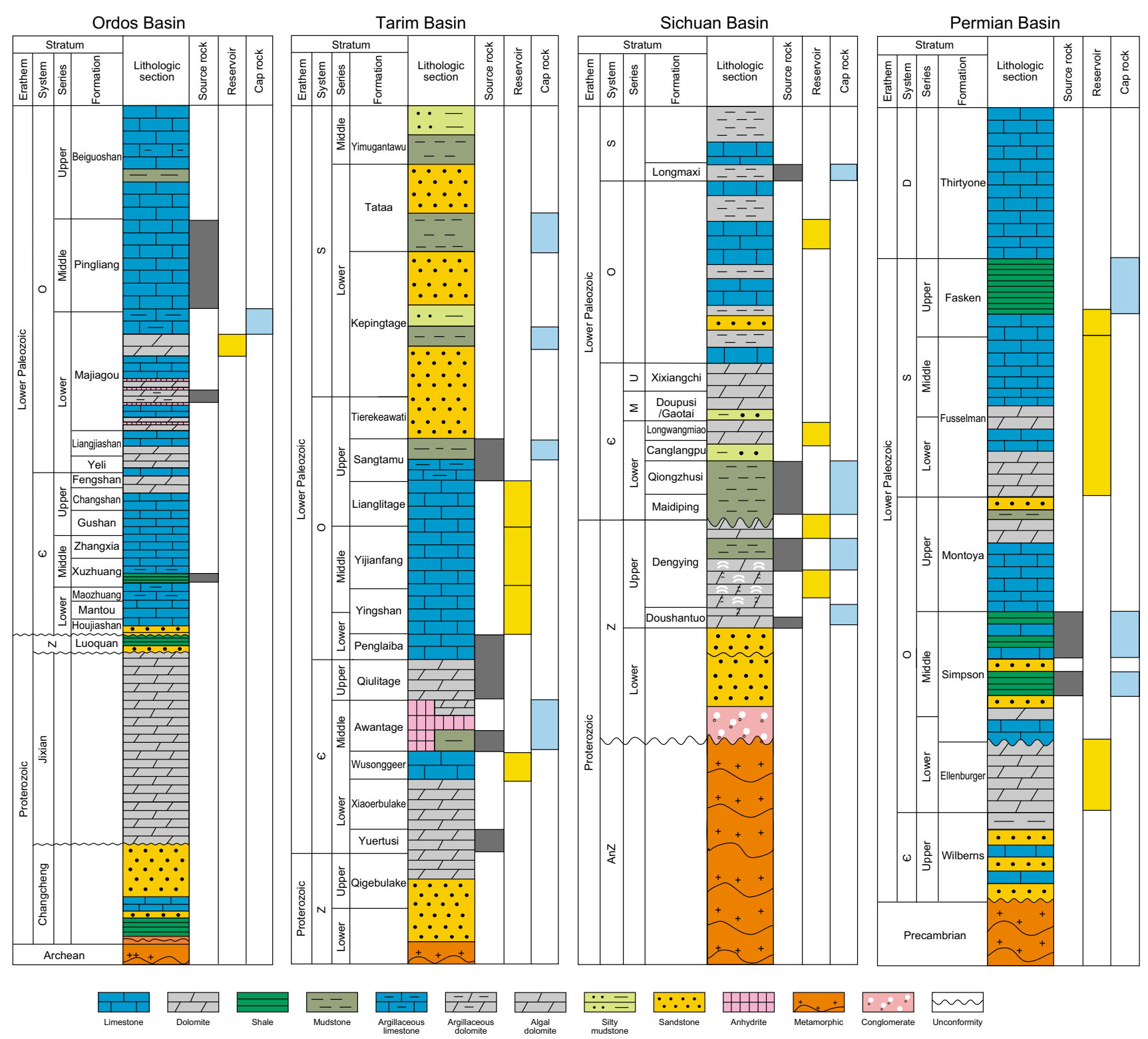

Fig. 3 Stratigraphic profiles and source-reservoir-cap rock assemblages of marine carbonate giant oil and gas fields in the Proterozoic-Lower Paleozoic strata worldwide

continental sedimentary systems since the end of the Cambrian period. In the Lower Paleozoic stratigraphic sections, several unconformities exit, and most of them between shallow shelf carbonate deposits (Hills 1984; Adams and Keller 1996). The Michigan Basin was deposited on a set of transgressive sandstones and sandy dolomites in the Cambrian period, which is in unconformable contact with Ordovician marine carbonate rocks, shales, and sandstones. In the Silurian period, carbonate rocks, reefs, and evaporites were alternately deposited and formed unconformable contact with the Devonian stratum (Fisher et al. 1988; Catacosinos et al. 1990). The sedimentary strata in the East Siberian Basin began in the Riphean in the Proterozoic period, and the major residual strata in the basin are Riphean, Vendian, Cambrian, Ordovician, and Silurian. Except for the Lower part of the Vendian and Silurian strata, which are mainly terrigenous clastic rock, the other strata are all carbonate (Khudoley et al. 2001; Zhu et al. 2012; Du et al. 2013). The marine carbonate strata in the Oman Basin are the Huqf Group, which is mainly Upper Proterozoic to Cambrian, formed during the transformation of the early rift into a depression basin in shallow sea, intermittent sea, and intertidal-subtidal zone depositional environments (Gorin et al. 1982; Filbrandt et al. 2006; Allen 2007; Zhu et al. 2014). 

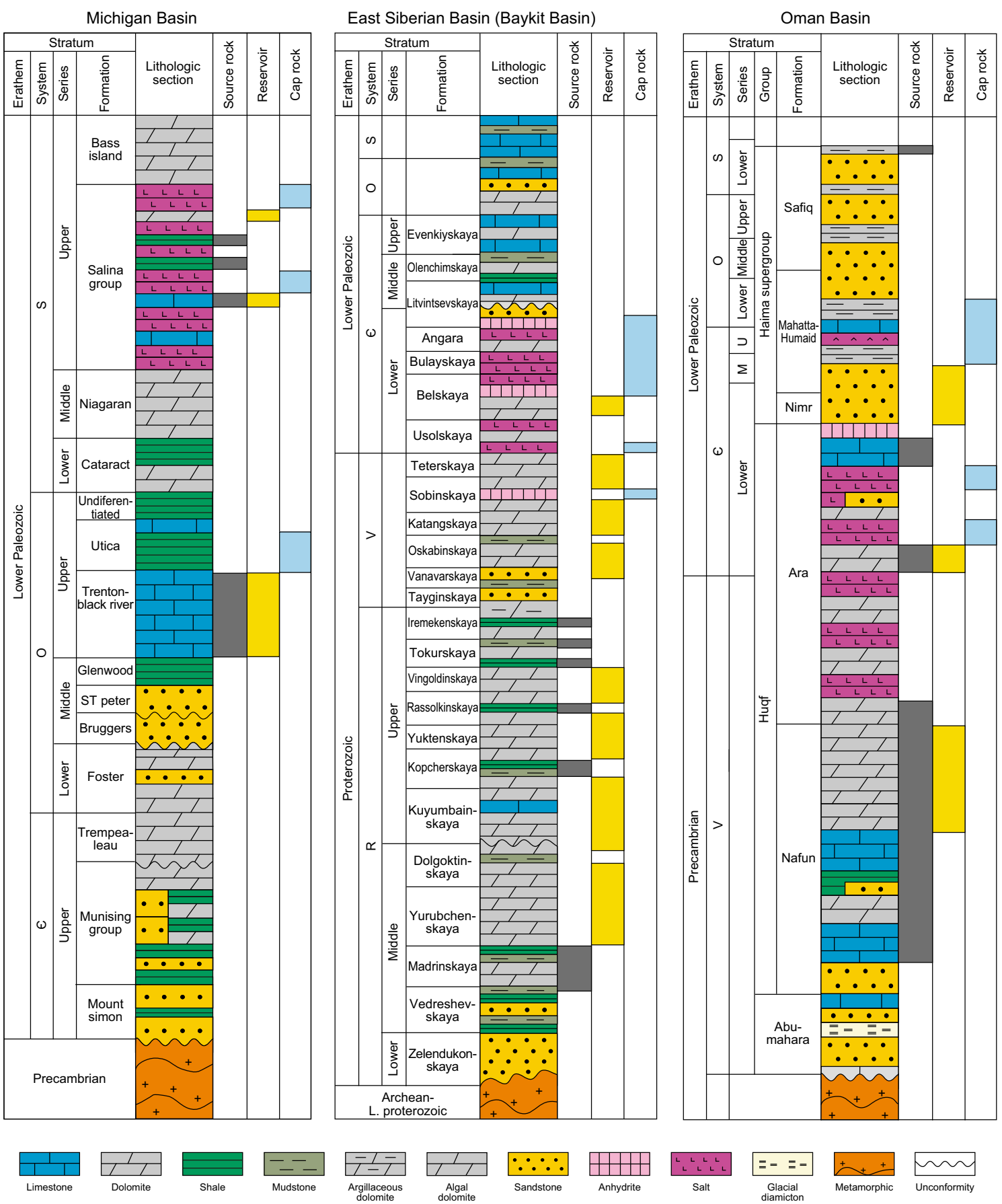

Fig. 3 continued

\section{Basic petroleum geological conditions of the giant oil and gas fields}

\subsection{Source rocks}

The developed horizons of the major source rocks in the PLP marine carbonate strata of the giant oil and gas fields range from the Proterozoic Riphean to the Paleozoic, varying by field (Table 2). The source rocks in the PLP were mainly formed in the cratons and passive continental margins. In the passive continental margins, the higher bioproductivity provided by oceanic upwelling and deepwater anoxic conditions was beneficial for forming highquality source rocks; in the cratons, large-scale 
transgression produced source rocks with a high abundance of organic matter. The depositional environments of the source rocks were mainly deep-water restricted conditions inside shelves and slopes (Zhang et al. 2005). In the basins with giant oil and gas fields, Riphean source rocks were developed in the Siberian plate (East Siberian Basin), and Sinian source rocks were mostly deposited in the Yangtze plate and the eastern margin of the Arabian plate (Oman Basin) (Liang et al. 2006; Liu et al. 2006; Tao et al. 2012; Nicholas and Gold 2012; Zou et al. 2014a). Because of the rise in sea level resulting from warmer climate and rapidly melting glaciers as the glacial period turned into the postglacial period, Cambrian, Ordovician, and Silurian source rocks were deposited (Zhang et al. 2005). Cambrian source rocks are situated in the Siberian plate (East Siberian Basin), Tarim plate (Tarim Basin), Yangtze plate (Sichuan Basin), and Arabian plate (Oman Basin) (Terken et al. 2001; Wang et al. 2002; Cocks and Torsvik 2011, 2013; Zou et al. 2014a); Ordovician source rocks are deposited in the passive continental margin of Laurentia (Permian Basin, Indiana-Ohio platform) and the Chinese continental plate (Tarim Basin, Ordos Basin) (Wang FY, Zhang BM, Zhang SC. Anoxia versus bioproductivity controls on the Cambrian and Ordovician marine source rocks in Tarim Basin, China. AAPG Annual Meeting 2002; Cocks and Torsvik 2011, 2013); and Silurian source rocks were mainly deposited in Laurentia (Michigan Basin) (Klemme and Ulmishek 1991; Zhou et al. 2014).

The source rocks are mainly composed of mudstone and shale, followed by marl and argillaceous dolomite. The source rocks are often thick, with a cumulative thickness exceeding $100 \mathrm{~m}$ (up to $600 \mathrm{~m}$ ). Organic matter types are dominated by type I and II, which are high-quality organic matter with high hydrocarbon generation potential. Because there were no terrestrial higher plants on Earth before the Devonian period, the composition of organic matter in the marine sedimentary strata is very similar all over the world, being mainly pelagic or benthic algae (Bazhenova 2009; Chen et al. 2012, 2013). The abundance of organic matter in the source rocks is highly variable and is closely related to the lithology. For example, the abundance of organic matter in shales is often higher than that in carbonate rocks. There has been some disagreement regarding the lower limit of the abundance of organic matter in effective marine hydrocarbon source rock; some studies have shown that the limit is lower in carbonate than shale source rocks (Peters 1986; Jarvie 1991; Jin 2005; Peng et al. 2008), while others have found it to be similar, with the total organic carbon (TOC) being greater than or equal to 0.5\% (Liang et al. 2000; Zhang et al. 2002; Dai et al. 2005a; Chen et al. 2012). The TOC in PLP marine carbonate rocks of the giant oil and gas fields is greater

Table 2 Source rock parameters for marine carbonate giant oil and gas fields in the Proterozoic-Lower Paleozoic strata worldwide

\begin{tabular}{|c|c|c|c|c|c|c|}
\hline $\begin{array}{l}\text { Name of giant oil and } \\
\text { gas field }\end{array}$ & Formation/age & Lithology & $\begin{array}{l}\text { Thickness, } \\
\mathrm{m}\end{array}$ & $\begin{array}{l}\text { Type of } \\
\text { organic matter }\end{array}$ & TOC, $\%$ & $R_{\mathrm{o}}, \%$ \\
\hline \multirow[t]{2}{*}{ Jingbian } & Benxi/C ${ }_{2}$-Taiyuan, Shanxi/ $\mathrm{P}_{1}$ & Coal, shale & $8-300$ & III & $2-83.2$ & $>1.5$ \\
\hline & Pingliang $/ \mathrm{O}_{2}$ & Shale, limestone & $400-500$ & $\mathrm{I} / \mathrm{II}$ & $0.4-1.81$ & $2.07-2.68$ \\
\hline \multirow[t]{2}{*}{ Tazhong 1} & $\begin{array}{l}\text { Yijianfang-Tumuxiuke, } \\
\text { Lianglitage/ } \mathrm{O}_{2-3}\end{array}$ & Shale, lime mudstone & $200-400$ & $\mathrm{I} / \mathrm{II}$ & $0.5-5.54$ & $0.81-1.30$ \\
\hline & Yuertusi, Heituao/ $\mathrm{C}-\mathrm{O}_{1}$ & Shale, argillaceous limestone & $150-450$ & I & $0.5-12.5$ & $2.0-4.0$ \\
\hline \multirow[t]{2}{*}{ Tahe } & $\begin{array}{l}\text { Yijianfang-Tumuxiuke, } \\
\text { Lianglitage } / \mathrm{O}_{2-3}\end{array}$ & Shale, lime mudstone & $200-400$ & $\mathrm{I} / \mathrm{II}$ & $0.5-5.54$ & $0.81-1.30$ \\
\hline & Yuertusi, Heituao/ $\mathrm{C}-\mathrm{O}_{1}$ & Shale, marl & $150-450$ & I & $0.5-12.5$ & $2.0-4.0$ \\
\hline \multirow[t]{2}{*}{ Anyue } & Qiongzhusi/ $€_{1}$ & Shale, argillaceous dolomite & 50-200 & I & $0.5-8.49$ & $1.84-2.42$ \\
\hline & Dengying $/ Z_{2}$ & Shale & $10-30$ & I & $0.50-4.73$ & $3.16-3.21$ \\
\hline Verkhne-Vilyuchanka & Dalnetayginskiy/R & Limestone, marl & $300-500$ & I & $0.2-5.7$ & $2-3$ \\
\hline Kuyumba & Madrinskaya $/ \mathrm{R}_{2}$ & Shale & $200-300$ & I & $0.9-3.9$ & $2-4$ \\
\hline Talakan & Usolskaya/ $€_{1}$ & Shale, limestone, dolomite & 100-200 & I & $5-8$ & $>2$ \\
\hline Yurubcheno-Tokhomo & Madrinskaya/ $\mathrm{R}_{2}$ & Shale, marl & $150-370$ & I & $2-16.5$ & $>2$ \\
\hline Puckett & Simpson $/ \mathrm{O}_{2}$ & Shale & $330-600$ & II & $1.2-1.66$ & $1.97-2.56$ \\
\hline Gomez & Simpson $/ \mathrm{O}_{2}$ & Shale & $330-600$ & II & $1.2-1.66$ & $1.97-2.56$ \\
\hline Niagaran Reef Trend & Salina A-1/S ${ }_{3}$, Niagaran $/ \mathrm{S}_{2}$ & Lime mudstone, shale & $15-40$ & $\mathrm{I} / \mathrm{II}$ & $0.4-3.5$ & $0.89-1.75$ \\
\hline Lima-Indiana Trend & Point Pleasant, Utica/ $\mathrm{O}_{3}$ & Shale, Lime mudstone & $60-90$ & II & $2-3$ & $0.6-1.0$ \\
\hline Makarem 1 & Huqf Supergroup/ $/ \mathrm{Pt}_{3}-\mathrm{C}_{1}$ & Argillaceous dolomite, shale & $50-400$ & $\mathrm{I} / \mathrm{II}$ & $4-7$ & $2.29-2.47$ \\
\hline
\end{tabular}

Compiled with data from IHS Energy (2009, 2013), C\&C Reservoirs (2005, 2009), and USGS (2007, 2008) 
than $1 \%$ with a high abundance of organic matter. Marine source rocks lacked higher plants in the PLP. Therefore, it is difficult to determine the maturation of the source rocks through vitrinite reflectance; usually, the $R_{\mathrm{o}}$ values are estimated from bitumen reflectance (Jacob 1985; Xiao 1992; Shi et al. 2015). The thermal evolution extent of the hydrocarbon source rocks is highly mature to over-mature in the thirteen giant oil and gas fields, except for the LimaIndiana Trend, which has a relatively low thermal evolution extent. The type of hydrocarbon is mainly natural gas, which is mostly sourced from oil cracking (Terken and Frewin 2000; Terken et al. 2001; Dakhnova et al. 2011; Jin 2012; Qiu et al. 2012; Zhou 2013).

\subsection{Reservoirs}

The developed horizons of the reservoirs in the giant oil and gas fields in the PLP marine carbonate strata are located from the Proterozoic Riphean to Silurian strata and vary by field (Table 3). The Riphean reservoir in the East Siberian Basin and the Sinian reservoir in the Anyue gas field in the Sichuan Basin are the oldest. The Ordovician is the most important oil and gas bearing formation in the PLP marine carbonate strata, followed by the Cambrian and Silurian. The burial depth of the reservoir is highly variable. If classified by average burial depth, the Tahe, Anyue, Gomez, and Makarem 1 oil and gas fields are ultradeep ( $>4500 \mathrm{~m}$ ); the Jingbian, Tazhong 1, and Puckett are deep (3500-4500 m); the Kuyumba and YurubchenoTokhomo are mid-deep (2000-3500 m); and the VerkhneVilyuchanka, Talakan, Niagaran Reef Trend, and LimaIndiana Trend are shallow $(<2000 \mathrm{~m})$. The lithology of the reservoirs is mainly dolomite, followed by limestone. The original reservoir sedimentary environments are mostly high-energy facies such as open platforms, platform margins, tidal flats, and shallow shelves. Reservoir space is mainly dissolved pores and cavities - intercrystalline pores and fractures with high heterogeneity. The average matrix porosity is generally less than $10 \%$ with a wide range of permeability. Usually, in the fractured zone, permeability increases exponentially (Pang et al. 2015). For example, the reservoir matrix porosity in the Lima-Indiana Trend oil and gas field is generally $<3.5 \%$ with a permeability of less than $0.1 \times 10^{-3} \mu^{2}$. However, in the reservoir near the fault zone, the porosity could be up to $6 \%$ with a permeability of up to $600 \times 10^{-3} \mu^{2}$. Because of the development of dissolved pores and fractures, the real porosity and permeability are higher than those measured in the carbonate rock matrix. There is a somewhat negative correlation between the porosity and the top burial depth of the reservoir; that is, the greater the burial depth is, the lower the porosity is (Fig. 4). This is the result of deep diagenesis of the reservoirs, such as compaction, cementation, and filling. The reservoir types are mainly karst and reef-shoal facies (Table 3).

\subsection{Cap rock}

Cap rock is one of the key factors affecting hydrocarbon accumulation. High-quality cap rock is crucial for the preservation of giant oil and gas fields in the PLP marine carbonate strata, because they are old and have experienced multiple tectonic movements (Zhang et al. 2014a). The lithology of cap rock in the giant oil and gas fields in the PLP marine carbonate strata is mainly evaporite and shale, followed by dense carbonate rock (Table 4). The thickness and lithology are two factors affecting the sealing ability. Although thicker cap rock more effectively prevents oil and gas from leaking and escaping, cap rock thickness is proportional to the spatial sealing area: the thicker the sealing cover is, the greater the oil and gas preservation is (Lv et al. 2005). The cap rock thickness of the giant oil and gas fields in the PLP marine carbonate strata usually exceeds $100 \mathrm{~m}$ (up to $600 \mathrm{~m}$ ), and it has a positive correlation with oil and gas reserves (Fig. 5). Furthermore, the lithology of cap rock influences its sealing ability. Evaporite cap rock is the most capable because of its considerable plasticity (Jin 2012). Ten of the thirteen giant oil and gas fields have developed direct evaporite cap rocks, including the fields containing the first eight recoverable reserves. In the Niagaran Reef Trend and Talakan fields, the cap rocks are less thick but the reserves are large, because their high-quality evaporite cap rocks played a key role in hydrocarbon preservation (Table 4).

\subsection{Hydrocarbon generation evolution}

\subsubsection{Hydrocarbon generation models}

Through comparative analyses of the sedimentary and burial histories of marine source rock in the PLP giant oil and gas fields, hydrocarbon generation models may be classified into four patterns: (1) early deep burial followed by continuous subsidence; (2) shallow burial, followed by uplift and then deep burial; (3) deep burial, followed by uplift, and then shallow burial; and (4) deep burial followed by continuous uplift (Zhang et al. 2007b; Zhu et al. 2010). The major source rock in the PLP giant oil and gas fields has been deeply buried and has a high degree of organic matter maturation.

The hydrocarbon generation model for the source rock in the PLP giant oil and gas fields in the Tarim, Oman, and Permian basins is (1): early deep burial followed by continuous subsidence (Fig. 6a-c). The common feature is that despite multiple tectonic uplifts, the burial depth of the major source rock generally continued to increase; in the 


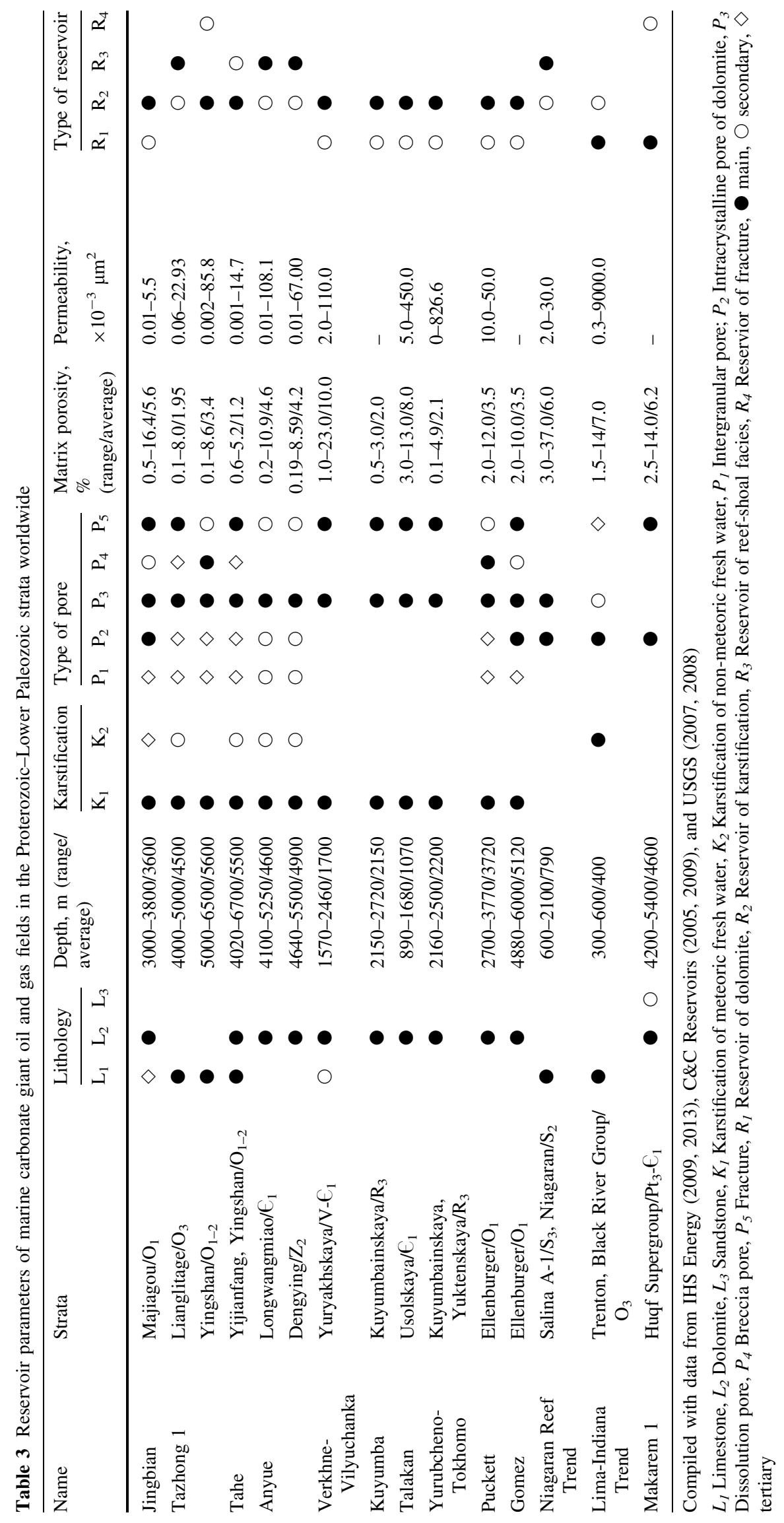




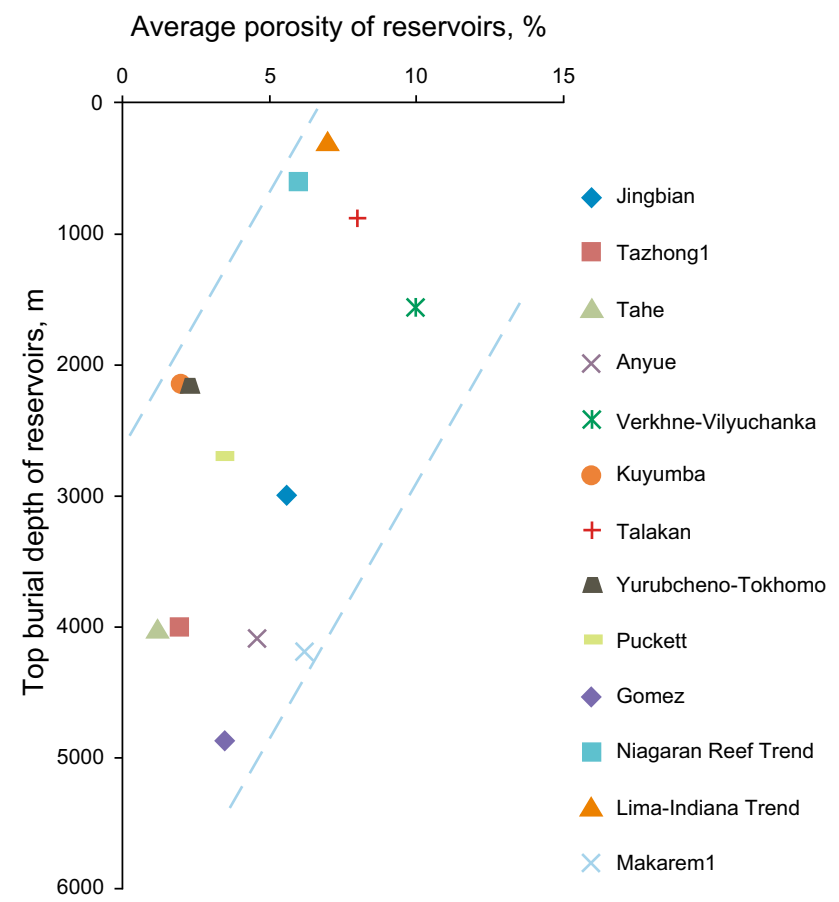

Fig. 4 Correlation between reservoir porosity and top burial depth for marine carbonate giant oil and gas fields in the Proterozoic-Lower Paleozoic strata worldwide

early stages (Caledonian and Hercynian), these basins had a higher subsidence rate, resulting in the source rock entering the oil window earlier. Because of differences in tectonic activities, the extent of hydrocarbon generation evolution varies by basin. The Middle and Lower Cambrian source rock in the Tarim Basin reached the peak of the oil generation stage in the late Caledonian-early
Hercynian, the condensate oil and wet gas generation stage in the late Hercynian, and the dry gas generation stage in the Himalayan period. The Middle and Lower Ordovician source rock was at low maturity in the late Caledonian and early Hercynian periods and reached the peak of the oil generation stage in the late Hercynian, and the condensate oil and wet gas generation stage in the Yanshanian and Himalayan periods. The Upper Ordovician source rock matured in the late Hercynian and reached the peak of the oil generation stage in the late Yanshanian and the condensate oil stage in the Himalayan (Zhao et al. 2008; Jin et al. 2012). The source rock in the Huqf Supergroup of the Oman Basin was most deeply buried in the late Permian to Tertiary periods, which was the main period of hydrocarbon generation and expulsion (Terken et al. 2001). The Ordovician Simpson shale in the central platform of the Permian Basin sank deep enough to enter the oil window in the late Permian. In the subsequent $210 \mathrm{Ma}$ years, it was consistently in an effective hydrocarbon generation and expulsion period, reaching its peak in the Late Triassic and ending in the middle Tertiary period (Fan 2005; Dutton et al. 2005).

The hydrocarbon generation model for the source rock in the PLP giant oil and gas fields in the Ordos Basin and Sichuan Basin is (2): shallow burial, followed by uplift, and then deep burial. The major source rock was buried in the Caledonian period and began to generate oil, but subsequently experienced uplift in the Hercynian period and continued to settle in the late Hercynian, reaching its deepest in the Yanshanian period, when it attained its peak hydrocarbon generation and expulsion. During the Himalayan stage, it was uplifted gradually (Fig. 6d, e). The Ordovician

Table 4 Cap rock parameters for marine carbonate giant oil and gas fields in the Proterozoic-Lower Paleozoic strata worldwide

\begin{tabular}{|c|c|c|c|}
\hline $\begin{array}{l}\text { Name of giant oil and } \\
\text { gas field }\end{array}$ & Formation/age & Lithology & $\begin{array}{l}\text { Average } \\
\text { thickness, } m\end{array}$ \\
\hline Jingbian & Benxi/C ${ }_{2}$, Majiagou/O ${ }_{1}$ & Evaporite, shale & 227 \\
\hline Tazhong 1 & Sangtamu $/ \mathrm{O}_{3}$, Yingshan, Penglaiba/ $\mathrm{O}_{1}$ & Shale, carbonate & 125 \\
\hline Tahe & Bachu/C, $\mathrm{O}_{1}$ & Shale, carbonate, evaporite & 200 \\
\hline Anyue & $\mathrm{T}_{1-2}, \mathrm{P}_{2}$, Qiongzhusi/ $€_{3}$ & Shale, evaporite & 150 \\
\hline Verkhne-Vilyuchanka & Usolskaya/ $€_{1}$ & Evaporite & 150 \\
\hline Kuyumba & $\mathrm{R}_{3}-\mathrm{C}$ & Evaporite, carbonate & 100 \\
\hline Talakan & Usolskaya/ $€_{1}$ & Evaporite & 70 \\
\hline Yurubcheno-Tokhomo & $\mathrm{V}-\mathrm{E}$ & Evaporite, shale, carbonate & 160 \\
\hline Puckett & Simpson/O $\mathrm{O}_{2}$, Mississippi & Shale & 120 \\
\hline Gomez & Simpson/O $\mathrm{O}_{2}$, Mississippi & Shale & 120 \\
\hline Niagaran Reef Trend & Sanila group $/ \mathrm{S}_{3}$ & Carbonate, evaporite & 40 \\
\hline Lima-Indiana Trend & Trenton, Utica/O $\mathrm{O}_{3}$ & Shale, evaporite, carbonate & 255 \\
\hline Makarem 1 & Mahwis/ $€_{1-2}$ & Shale, evaporite & 120 \\
\hline
\end{tabular}

Compiled with data from IHS Energy (2009, 2013), C\&C Reservoirs (2005, 2009), and USGS (2007, 2008) 


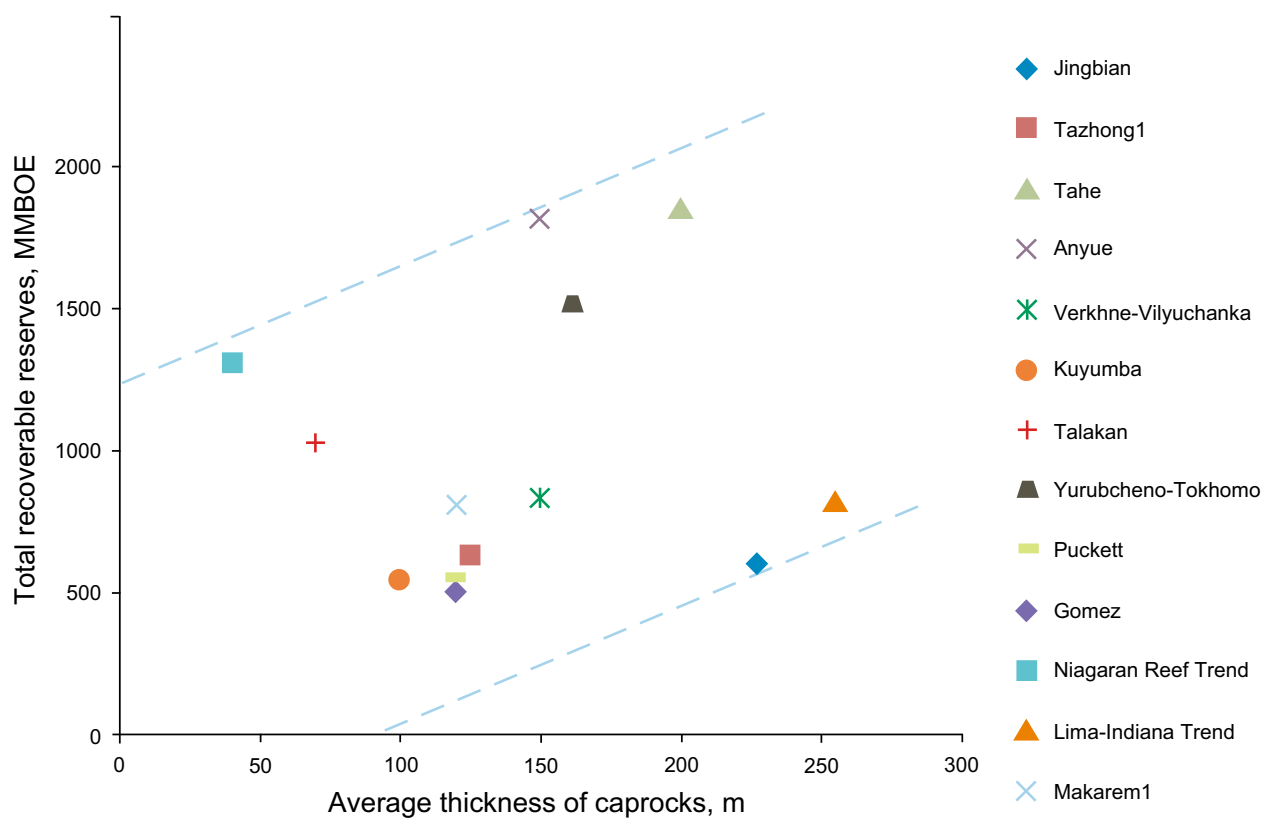

Fig. 5 Correlation between recoverable reserves and average cap rock thicknesses for marine carbonate giant oil and gas fields in the Proterozoic-Lower Paleozoic strata worldwide

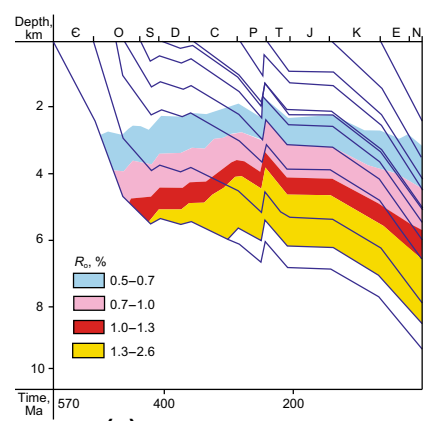

(a) Tarim Basin (Manjiaer Sag)

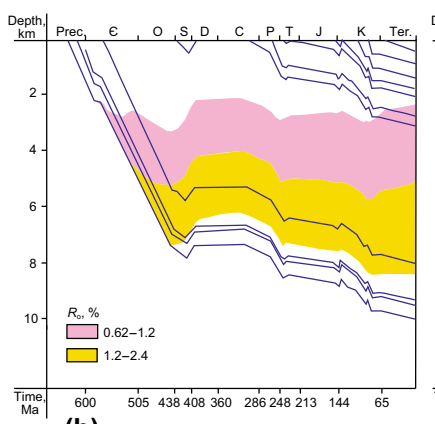

(b) Oman Basin (Central Oman Salt Basin)

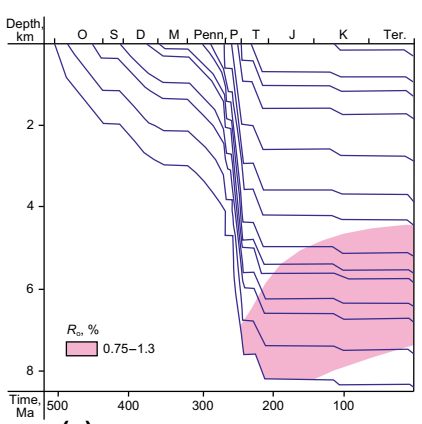

(c) Permain Basin (Central Basin Platform)

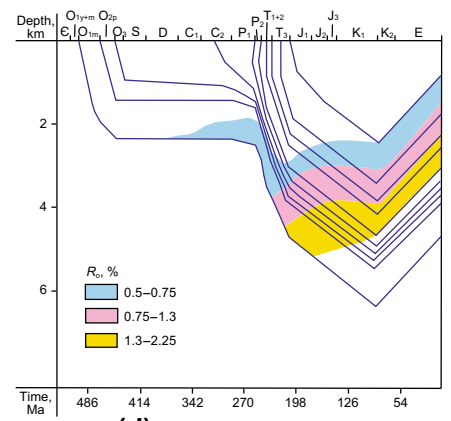

(d) Ordos Basin (Central Ordos)

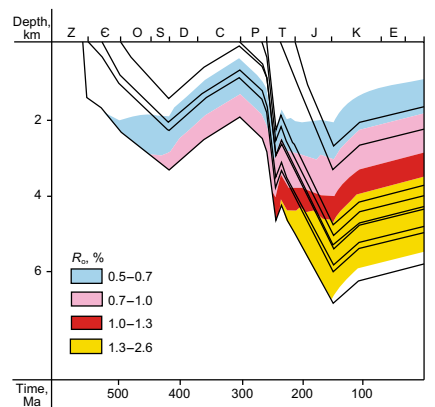

(e) Sichuan Basin (Gaoshiti-moxi)

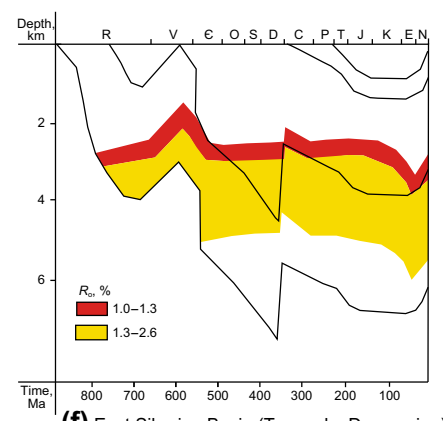

(f) East Siberian Basin (Tunguska Depression)

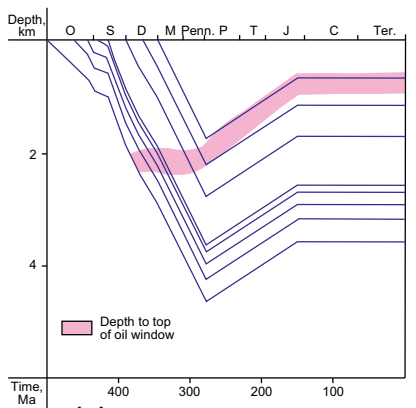

(g) Michigan Basin (Central Michigan)

Fig. 6 Burial and thermal evolution histories of the basins with marine carbonate giant oil and gas fields in the Proterozoic-Lower Paleozoic strata worldwide (Zhao et al. 2008; Wang and Jin 2007; Ross 1986; Lei and Zhang 1998; Wei et al. 2015a; Li et al. 2000; Catacosinos et al. 1990)

carbonate source rock in the Ordos Basin began to generate oil in the Middle Triassic, reached peak oil generation in the Jurassic, and over-matured to generate gas in the Early Cretaceous (Tang et al. 2000). The Lower Cambrian source rock in the Sichuan Basin entered a mature stage during the
Caledonian movement and stopped generating hydrocarbon as a result of the Caledonian uplifting. It reached its peak hydrocarbon generation and expulsion stage in the Permian to Triassic periods, and then this ended in the early Cretaceous (Liu et al. 2009b; Sun et al. 2010). 
The hydrocarbon generation depressions in the East Siberian Basin follow model (3): They experienced multiperiod tectonic movements of deep burial, followed by uplift, and then shallow burial (Fig. 6f). The Riphean source rock reached its maximal burial depth after the sedimentary stages of the Riphean rift and Vendian-Paleozoic stable platform. The whole basin was uplifted because of strong Hercynian orogeny movements in the late Paleozoic, while the marginal depressions were shallowly buried in the Mesozoic and Cenozoic. The Riphean source rocks in the Tunguska Depression began to mature and generate oil in the Vendian, reaching their peak in the Ordovician period. A large number of oil and gas reservoirs were formed in the early Paleozoic, while gas was mainly generated in the Early Triassic period. The main period of hydrocarbon generation and expulsion of the Cambrian source rocks was during the Devonian to Triassic periods (Zhu et al. 2012).

The hydrocarbon generation model for source rocks in the PLP giant oil and gas fields in the Michigan Basin and Indiana-Ohio platform in North America follow model (4): deep burial followed by continuous uplift (Fig. 6g). During the Ordovician to Mississippian periods, the basin was at a stable deposition stage and had not experienced much tectonic movement. From the late Pennsylvanian period, the basin began to uplift and was subjected to erosion until the Holocene. The major carbonate source rocks in the Salina A-1 group of the tidal flat facies of the Upper Silurian experienced early continual settlement, and their main hydrocarbon generation and expulsion period was between the Devonian and Carboniferous periods (Cercone 1984; Charpentier RR. A summary of petroleum plays and characteristics of the Michigan basin. USGS Open-File Report 87-450R 1987).

In summary, since the major source rocks in the PLP giant oil and gas fields experienced long periods of burial and thermal evolution, they had early and long-lasting hydrocarbon generation times. Except for the relatively simple tectonic movements of pattern (4), the other three models involved multiperiod tectonic movements, and thus multiperiod hydrocarbon generation and expulsion are the most favorable conditions for the formation of giant oil and gas fields.

\subsubsection{Origin of gas}

According to the four hydrocarbon generation models, there are some differences in the hydrocarbon-generating processes of the major source rocks in the PLP giant oil and gas fields. The first three models have the following common features. First, the basins underwent multistage tectonic movements, and the source rocks were buried for a long duration with great burial depth and a high degree of thermal evolution; the resulting oil and gas fields that formed are dominated by hydrocarbon gas reservoirs (such as Jingbian, Anyue, Puckett, Gomez and Makarem 1). Second, the early-formed oil reservoirs are preserved in some areas, and the oil and gas fields feature the coexistence of oil and gas or are dominated by oil (such as the giant oil and gas fields in the Tarim Basin and East Siberian Basin). Although in the basins of model (4), the source rocks were buried deeply in the early period with mature to highly mature thermal evolution and massive hydrocarbon generation, later continuous uplift ceased the hydrocarbon generation much earlier. The present burial depth of the source rocks is relatively shallow, and the oil and gas fields formed are dominated by liquid oil (such as the Niagaran Reef Trend and Lima-Indiana Trend oil and gas fields).

Gas is the most important resource in the PLP marine strata (Wang and Han 2011; Wang et al. 2013a) and has many types of hydrocarbon sources (Zhao et al. 2006; Liu et al. 2012a). Three major types of hydrocarbon sources exist: insoluble, soluble, and acid-soluble organic matter. Some insoluble hydrocarbon sources are aggregated (such as coal and oil shale) and others are dissipated (such as different types of kerogens). The soluble hydrocarbon sources include aggregated, dissipated, and transformed soluble organic matter; aggregated soluble organic matter is the oil reservoir formed in the early stage (paleo-oil reservoirs), dissipated soluble organic matter refers to chloroform asphalt " $\mathrm{A}$ " inside the source rocks and soluble organic matter migrated outside them (such as bitumen in migration paths or hydrocarbons without reservoir-forming), and transformed soluble organic matter comprises varieties of evolved or oxidized bitumen. Acid-soluble organic matter indicates that the hydrocarbon source existed as organic acid salts in the geological body (Liu et al. 2012a).

The origins of gas in the PLP marine strata are characterized by multiple hydrocarbon generation conversion processes, and oil-cracking gas is one of the most important types (Zhao and Zhang 2001; Zhao et al. 2006; Zhang and Zhu 2006; Wang et al. 2009a; Zhang et al. 2014b; Zheng et al. 2015). The Anyue gas field in the Sichuan Basin is a typical case of oil-cracking gas. Its Sinian source rocks began to generate oil in the middle to late Cambrian period, stopped generating oil during the Caledonian uplift movement, and generated oil once again from the Permian to Triassic periods. Meanwhile, the liquid hydrocarbons from source rocks were accumulated into the GaoshitiMoxi paleo-uplift and formed paleo-reservoirs. Before the Late Triassic, oil began to crack into gas in the paleoreservoirs and oil and gas reservoirs were formed; oil continually cracked into gas during the Late Triassic to Cretaceous periods, and giant oil-cracking gas reservoirs were formed. The hydrocarbon-generating process in 
Cambrian source rocks was similar to that in Sinian source rocks with later periods of hydrocarbon generation and oil cracking (Wei et al. 2015a).

\section{Reservoir types and distribution characteristics of the giant oil and gas fields}

\subsection{Reservoir types}

The reservoir types of the giant oil and gas fields in the PLP marine carbonate strata are complex and diverse. The most highly developed are stratigraphic reservoirs and structural-lithologic, structural-stratigraphic, and lithologicstratigraphic reservoirs, followed by structural reservoirs and then lithologic reservoirs. In the thirteen giant oil and gas fields, six have stratigraphic reservoirs; five have structural-lithologic, structural-stratigraphic, or lithologicstratigraphic reservoirs; four have structural reservoirs, and three have lithologic reservoirs (Table 5). Among the fields with reserves of more than 1000 million barrels, the Tahe, Talakan, and Yurubcheno-Tokhomo fields have mainly stratigraphic reservoirs, while the Niagaran Reef Trend field is reef lithologic, and the Anyue gas field is both structural-lithologic (Cambrian Longwangmiao Formation) and structural-stratigraphic (Sinian Dengying Formation) (Fig. 7).

\subsection{Characteristics of distribution}

The distribution of the giant oil and gas fields in the PLP ancient marine carbonate strata was greatly influenced by regional paleo-uplift. The fields mainly developed in the paleo-uplift area, slope area, and platform margin reefshoal bodies in the basins (Table 5). There are more oil and gas fields in the slope area than in the higher part of the uplift. This is mainly because the high part has been strongly denuded and destroyed, resulting in the escape of oil and gas accumulated in the early stage. For example, the Tazhong 1 and Tahe fields are located in the slopes of Tazhong and Tabei paleo-uplifts in the Tarim Basin (Jiang et al. 2010), and the Jingbian gas field is situated in the Yishan paleo slope in the Ordos Basin. Vertically, karst reservoirs in the weathering crust of Ordovician carbonate rocks are the main production layers. The Anyue field is located in the north slope zone of the Weiyuan uplift and gas accumulated under the control of the Gaoshiti-Moxi paleo-uplift. The dolomite grain beach reservoir body was mainly developed in the Cambrian period (Zou et al. 2014b; Wei et al. 2015b; Zhu et al. 2015; Li et al. 2015). The Gomez and Puckett fields are located at the anticlinal flanks of the Delaware and Val Verde basins. The production layer is the weathered crystalline dolomite of the Lower Ordovician Elenburger Group (Ijirigho and Schreiber 1988). The Makarem 1 gas field is located in the

Table 5 Reservoir types and locations in marine carbonate giant oil and gas fields in the Proterozoic-Lower Paleozoic strata

\begin{tabular}{|c|c|c|}
\hline Name & Type of the main oil/gas reservoirs & Location \\
\hline Jingbian & Stratigraphic unconformity gas reservoirs & Yishan slope of Ordos Basin \\
\hline Tazhong 1 & $\begin{array}{l}\text { Fault-anticline oil and gas reservoirs, reef-shoal } \\
\text { facies oil and gas reservoirs }\end{array}$ & $\begin{array}{l}\text { TZ1 faulted slope-break zone in the northern slope of } \\
\text { Tazhong low uplift of Tarim Basin }\end{array}$ \\
\hline Tahe & Stratigraphic unconformity oil reservoirs & $\begin{array}{l}\text { Slope in the southern margin of Akekule rise of Tabei uplif } \\
\text { in Tarim Basin }\end{array}$ \\
\hline Anyue & Structural-lithologic gas reservoirs & North slope of Weiyuan uplift in Sichuan Basin \\
\hline Verkhne-Vilyuchanka & Stratigraphic-structural gas reservoirs & Predpatom basin in East Siberian Basin \\
\hline Kuyumba & $\begin{array}{l}\text { Stratigraphic, structural, lithologic oil and gas } \\
\text { reservoirs }\end{array}$ & $\begin{array}{l}\text { The middle part of Baykit anticline of Kamal uplift in Eas } \\
\text { Siberian Basin }\end{array}$ \\
\hline Talakan & Structural oil and gas reservoirs & Nepa-Botuobin anticline in East Siberian Basin \\
\hline Yurubcheno-Tokhomo & Buried hill oil and gas reservoirs & $\begin{array}{l}\text { The middle part of Baykit anticline of Kamal uplift in Eas } \\
\text { Siberian Basin }\end{array}$ \\
\hline Puckett & $\begin{array}{l}\text { Stratigraphic-structural (fault-anticline) gas } \\
\text { reservoirs }\end{array}$ & Flanks of anticlines in Delaware Basin in Permian Basin \\
\hline Gomez & Stratigraphic-anticline gas reservoirs & Flanks of anticlines in Delaware Basin in Permian Basin \\
\hline Niagaran Reef Trend & Reef oil and gas reservoirs & Marginal platform of Michigan Basin \\
\hline Lima-Indiana Trend & $\begin{array}{l}\text { Anticline oil and gas reservoirs, stratigraphic oil } \\
\text { and gas reservoirs }\end{array}$ & Indiana-Ohio Platform \\
\hline Makarem 1 & Anticline gas reservoirs & Makarem paleo-uplift \\
\hline
\end{tabular}

Compiled with data from IHS Energy (2009, 2013), C\&C Reservoirs (2005, 2009), and USGS (2007, 2008) 


\section{Anticline}

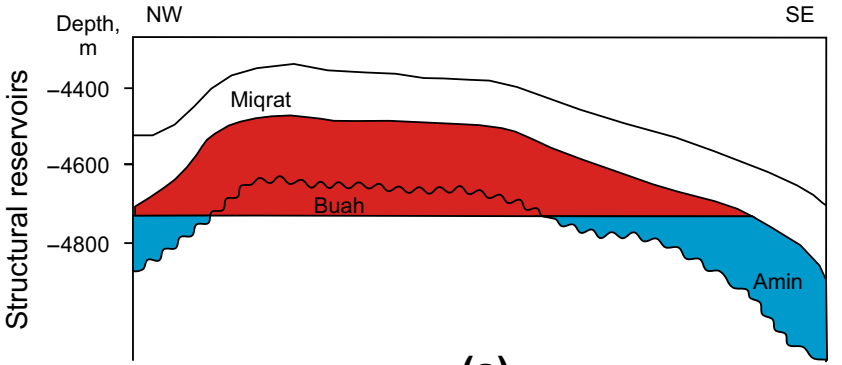

(a)

Unconformity of Lateral Barrier

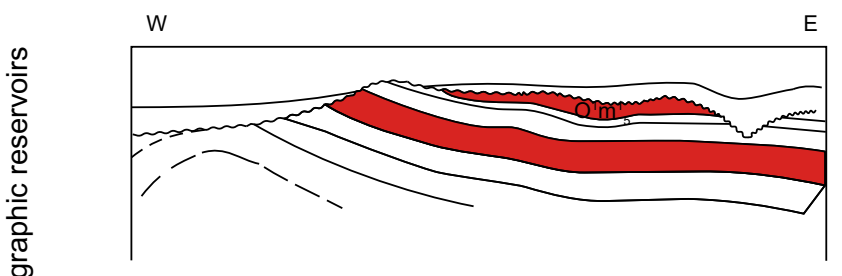

(c)

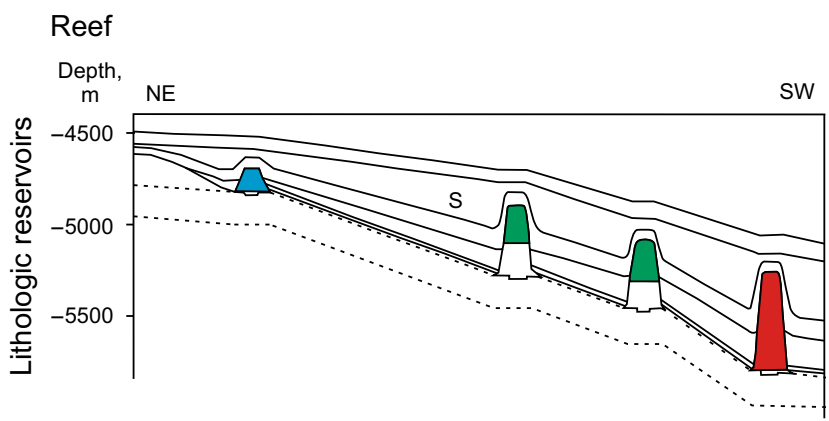

(e)

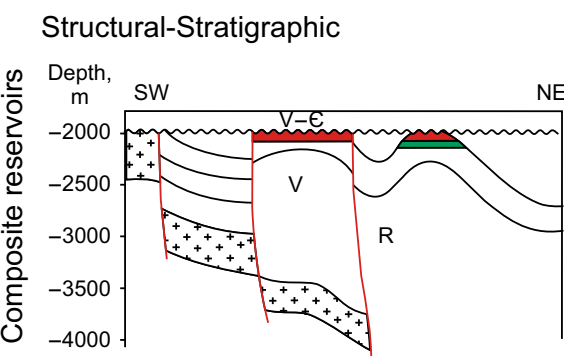

(g)
Structural-Lithologic Depth,

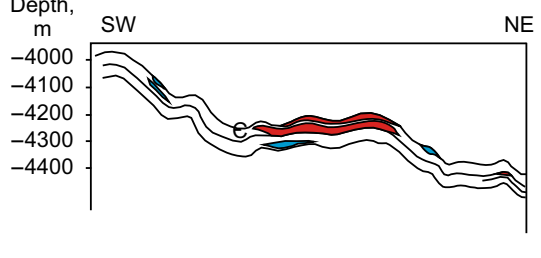

(h)

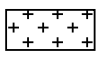

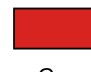

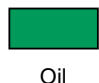

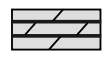

Dolomite
Basement

Fig. 7 Proterozoic-Lower Paleozoic marine giant oil and gas reservoir types. (a) Makarem 1 gas reservoir; (b) Verkhne-Vilyuchanka oil and gas reservoir; (c) Jingbian gas reservoir; (d) YurubchenoTokhomo oil and gas reservoir; (e) Niagaran Reef Trend oil and gas

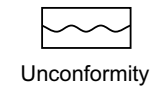
reservoir

\section{Faulted Anticline}

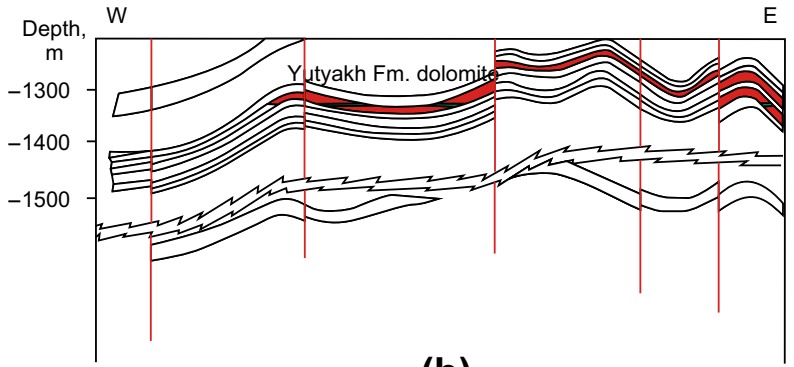

(b)

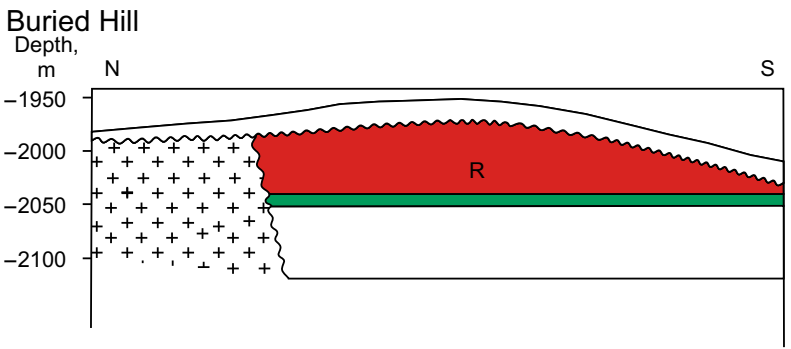

(d)

\section{Diagenetic Trap}

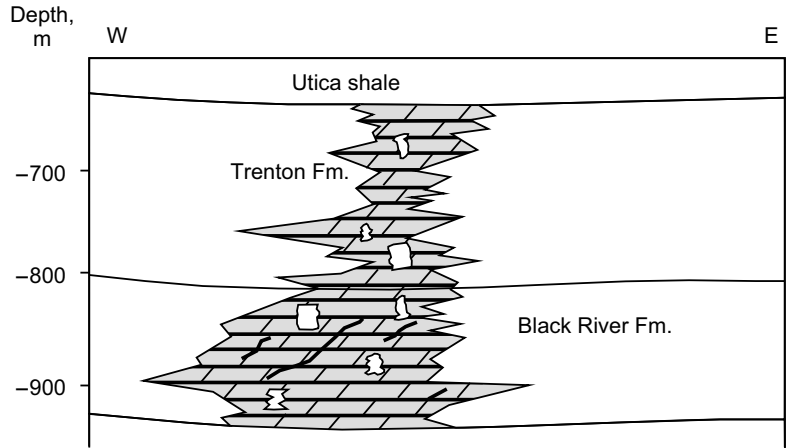

(f)

Depth,

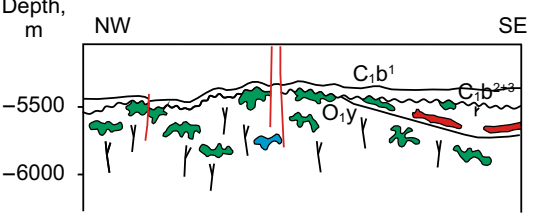

(i)
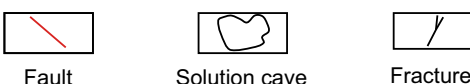

Solution cave

Fracture

reservoir; (f) Lima-Indiana Trend oil and gas reservoir; (g) Kuyumba oil and gas reservoir; (h) Anyue gas reservoir; (i) Tahe oil and gas 
Makarem paleo-uplift zone in the Oman Basin. The carbonate reservoirs are Ara subsalt and intersalt dolomite belts, overlaid with thick evaporites of the Ara Group that provide high-quality regional cap rocks (Alkindi and Richard 2014). The Niagaran Reef Trend field is mainly distributed on the slope of annular deposits between the carbonate platform and the center of the Michigan Basin, where oil and gas are accumulated in the middle Silurian pinnacle reefs (Ritter 2008). The four fields in the East Siberian Basin are mainly distributed on the Nepa-Botuobin and Baykit paleo-uplifts and their slopes. The gas and oil reserves in the Baykit uplift are mostly distributed in the middle part of the secondary low uplifts, while those in the Nepa-Botuobin uplift are mainly at the top or southern slope. For example, the Yurubcheno-Tokhomo field is located in the middle part of the Kamo uplift in the Baikit Anticline. Within $100 \mathrm{~m}$ under the unconformity surface is a high oil and gas production segment. At the high position of the uplift, the dolomite experienced strong structural movements and dissolution. Dissolved pores, cavities, and fractures were well developed with highquality reservoir properties for oil and gas accumulation. Meanwhile, very thick evaporites were developed in the lower part of the Lower Cambrian strata in the central and southern regions, which acted as a high-quality regional cap layer preventing the upward migration of lower fluids and the dissipation of lower oil and gas (Kontorovich et al. 1981; Du et al. 2009).

\section{Main factors controlling the formation and distribution of the giant oil and gas fields}

Numerous studies have been conducted to define the factors that control the oil and gas enrichment in marine carbonate strata with respect to source rocks, reservoirs, cap rocks, unconformities, faults, paleo-uplifts, and slopes (Jin 2010, 2014; Jin et al. 2012; Zhao et al. 2012b; Pang et al. 2013, 2014; Zhao et al. 2007; Zhang et al. 2007b; Yi et al. 2012; Liu et al. 2009b; Sun et al. 2010; Wei et al. 2015a, b; Wang et al. 2013a; Zou et al. 2014b). Through the comparison of the formation conditions and distribution characteristics of the giant oil and gas fields in the PLP marine carbonate strata, it is clear that the main factors controlling the formation and distribution of the oil and gas fields are large-scale efficient hydrocarbon kitchens, favorable hydrocarbon accumulation zones, large-scale high-quality reservoirs, and a large area of high-quality cap rock.

\subsection{Large-scale efficient hydrocarbon kitchens}

Large-scale efficient hydrocarbon kitchens offer the essential material base for the formation of giant oil and gas fields. Ancient marine strata are characterized by multisource hydrocarbon generation. Based on their forming processes, these can be classified as original source rock, regenerative hydrocarbon source rock, and chemical hydrocarbon source rock (Liu et al. 2012a; Zhao et al. 2012b). The original source is sedimentary organic matter, which is the conventional parent material of the hydrocarbon generated from kerogen thermal degradation. The regenerative hydrocarbon sources and chemical hydrocarbon sources are derivatives of the original source. Large-scale efficient hydrocarbon kitchens here mainly refer to widely distributed original source rocks with a highly effective hydrocarbon generation ability. They meet the following three conditions. First, the hydrocarbon source rocks have a large distribution area (for example, effective source rocks in the Tarim, Sichuan, Ordos, East Siberian, and Oman basins are over $10 \times 10^{4}$ $\mathrm{km}^{2}$ in size). Second, they have a great abundance of organic matter, a high thermal evolution extent (Table 2), and a long period of immense hydrocarbon generation and expulsion. The average TOC of the hydrocarbon source rocks of the thirteen giant oil and gas fields is greater than 1\%. Except for the Lima-Indiana Trend, which is at a mature phase, the thermal evolution extent in these fields is highly mature to over-mature, and they have all experienced the full course of oil- and gas-forming processes. The regenerative hydrocarbon sources, paleo-oil reservoirs, and soluble organic matter (such as asphalts) inside and outside the source rock are important parent materials for gas formation in the highly mature to overmature stages. Third, they have a large effective hydrocarbon supplying area. The giant fields are mostly located near hydrocarbon kitchens. For example, the Tahe Oilfield is situated on the Akekule uplift in the Tarim Basin, and on three sides, it is surrounded by hydrocarbon source rocks with a short migration distance to supply sufficient oil and gas. The Jingbian gas field is located in the eastcentral Yishan slope in the Ordos Basin, which is adjacent to a hydrocarbon-generating depression. The vitrinite reflectance $\left(R_{\mathrm{o}}\right)$ of the upper Paleozoic source rock is greater than $1.5 \%$ and the hydrocarbon-generating intensity is generally greater than $20 \times 10^{8} \mathrm{~m}^{3} / \mathrm{km}^{2}$ with a sufficient supply of oil and gas (Yang et al. 2013). The hydrocarbon reservoirs on the Nepa-Botuoba and Paikit paleo-uplifts in the East Siberian Basin are flanked by Riphean hydrocarbon kitchens in the Yenisey and PrePatom Depressions (Fig. 8a). The two source kitchens have had long-term thermal evolution and are in highly mature to over-mature stages. The hydrocarbon of the Makarem 1 field in the Oman Basin is mainly generated from the high-quality source rocks of the Nafun Formation of the Huqf Group in the two large salt basins around the Makarem uplift (Fig. 8b). 


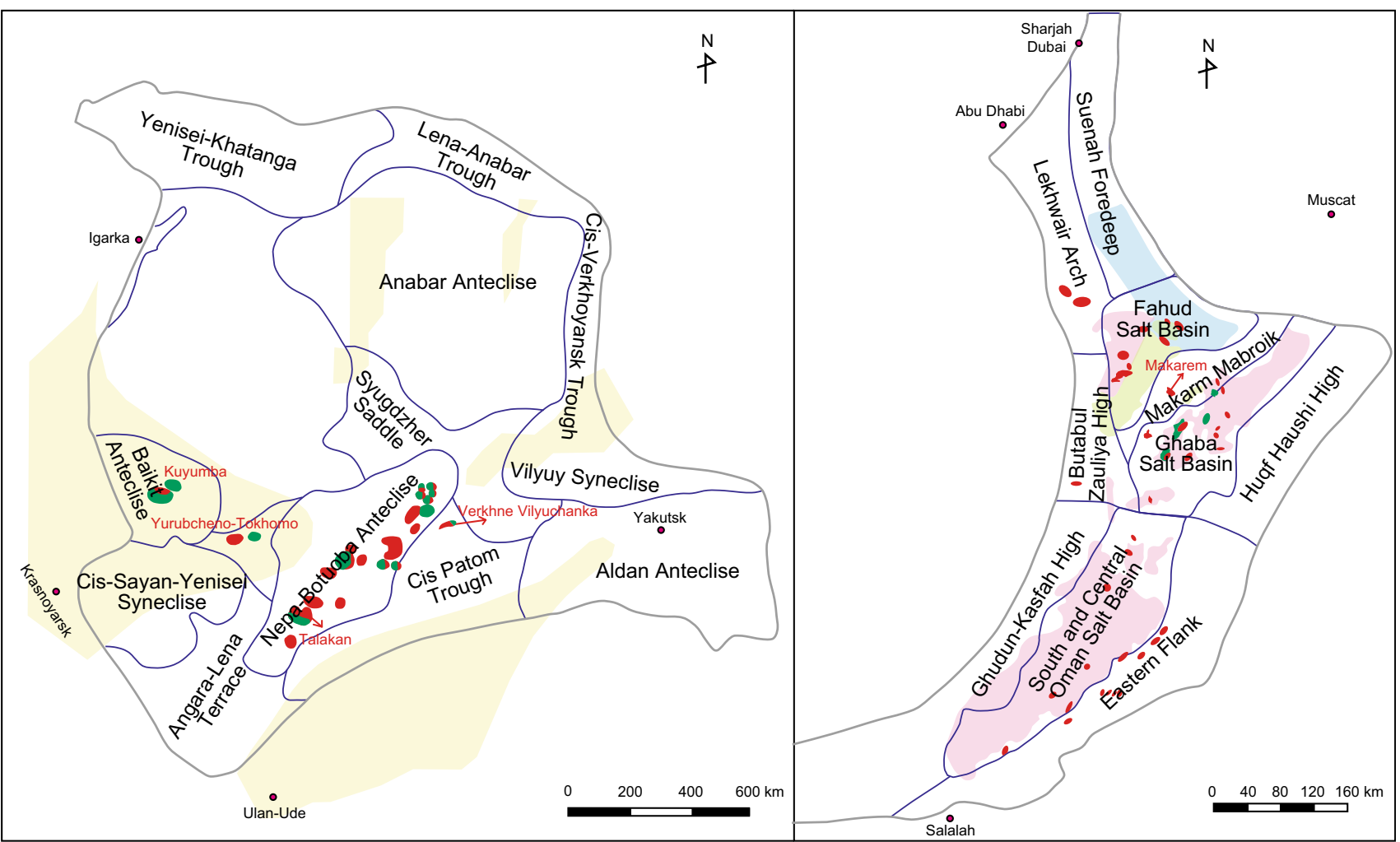

(a)

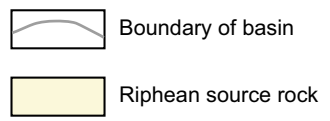

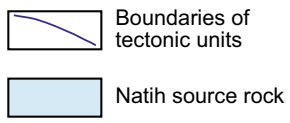

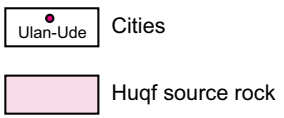

(b)

Fig. 8 Distribution relationships between the ancient marine carbonate giant oil and gas fields and source rocks in a the East Siberian Basin and b the Oman Basin (Zhu et al. 2012; Terken et al. 2001)

\subsection{Large-scale high-quality reservoirs}

Large-scale high-quality reservoirs have developed in the giant oil and gas fields in the PLP marine carbonate strata, with a distribution area ranging from a few to tens of thousands of square kilometers. They may be thick monolayers or vertically stacked reservoir layers of various types. The formation of high-quality reservoirs is integrated and controlled by many factors, such as the structure, deposition, diagenesis, and fluid (Tucker and Wright 1990; Moore 2001; Lucia 2007; Ma et al. 2011; Du et al. 2014; He et al. 2011b, 2016). Although the characteristics and formation mechanisms of the highquality reservoirs may be different (Table 3), they have some similarities. First, the original sedimentary environments are all high-energy facies, such as open platform, shallow continental shelf, tidal flat, platform edge reef, and shoal sedimentary facies of large area and heavy thickness. Second, they experienced diagenetic epigenesis evolution conducive to reservoir development; among these, dolomitization and supergene karstification play an important role for the development of high-quality reservoirs (Kupecz and Land 2009). Third, they experienced multiperiod tectonic movements, where structurepressure coupling controlled the development of the fractures in the reservoirs. These fractures not only expanded the reservoir spaces but also improved the reservoir permeability, providing spaces for the interaction between the rocks and acid fluids: $\mathrm{CO}_{2}$, in the early stage, and acid fluids such as $\mathrm{H}_{2} \mathrm{~S}$ in the late stage (Gale and Gomez 2007; Zhu et al. 2007; Xiang et al. 2010; Ma et al. 2011; Husnitdinov 2014). The multiperiod tectonic movements resulted in the uplift and erosion of strata, forming large unconformities and providing conditions for the formation of weathering crust karst reservoirs. For example, the multiperiod tectonic movements in the PLP marine strata in the Tarim, Sichuan, East Siberian, and Permian basins produced large-scale karst reservoirs (Postnikova et al. 2002; Dutton et al. 2005; Kang 2008; Zhang et al. 2007b; Luo et al. 2008; Liu et al. 2010; Zhao et al. 2012b; Wang et al. 2013b; Zhou 2013; Du et al. 2014; Yang et al. 2014). 


\subsection{Large area of high-quality cap rock}

Large-area distribution of high-quality cap rock and superior preservation conditions are key factors shaping the distribution of the ancient marine carbonate giant oil and gas fields. After comparing the basic geological characteristics of the ancient marine carbonate giant oil and gas fields worldwide, we found that these fields have developed one or more sets of high-quality regional cap rock (Table 4). High-quality cover, especially of gypsum-salt cap rock, is key to the formation of large- and mediumsized oil and gas fields (Jin et al. 2009; Jin 2014). For example, the Yurubcheno-Tokhomo field in the East Siberian Basin has Lower Cambrian thick gypsum-salt regional cap rock, which is widely distributed across the basin (Fig. 9). In the early and middle Cambrian, the East Siberian Basin was in an evaporated lagoon environment in a relatively closed sea, forming three sets of stably distributed gypsum-salt rock. The accumulated thickness of the regional gypsum-salt rock is $1000-1500 \mathrm{~m}$ with each single layer being $10-20 \mathrm{~m}$. These are interbedded with carbonate rocks, and the accumulated thickness of the pure salt layer is $300-400 \mathrm{~m}$. This stably distributed highquality regional cap rock provides superior preservation for oil and gas in the southern uplifts and fault terrace zones in the basin (Du et al. 2013).

\subsection{Favorable hydrocarbon accumulation zones}

Statistical analysis of the distributions of PLP marine carbonate giant oil and gas fields (Table 5) shows that they are mainly distributed in paleo-uplifts, slope zones, and platform margin reef-shoal bodies in the basins. The slope zones can be divided into depositional, structural, and superimposed slopes. The platform margin reef-shoal body is actually part of a platform margin slope zone, or a type of depositional slope. Therefore, in general, paleo-uplifts and slope zones are the most favorable hydrocarbon accumulation zones in the PLP marine carbonate sequences.

The paleo-uplifts and the slope zones in the basins are favorable directional zones for oil and gas migration (Zhou 2000; He et al. 2000; Jin et al. 2009; Jin 2010, 2012; Zhao et al. 2012b; Wei et al. 2015a; Zou et al. 2015). In marine carbonate basins, low- and high-energy facies are often superimposed on paleo-uplifts and slope zones during the deposition process of transgressive-regressive cycles. The reef and shoal deposits in the high-energy facies can form superior primary reservoirs, while shale and argillaceous carbonate rocks in the low-energy facies can directly develop into cap rocks, resulting in well-developed reservoir-caprock assemblages (Dutton et al. 2005; Lin et al. 2009; He et al. 2008). In addition, the paleo-uplifts and the

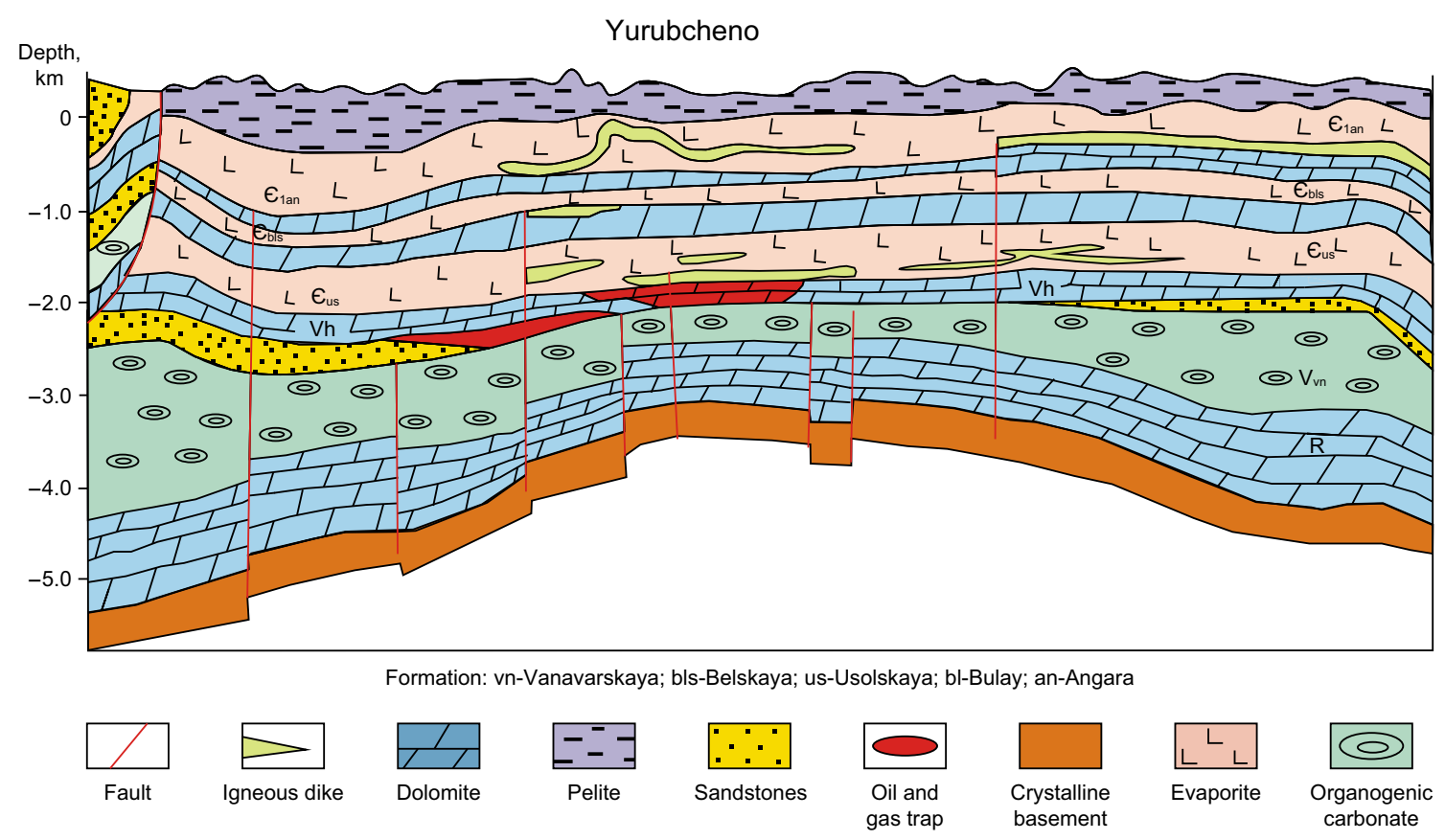

Fig. 9 Cap rock in the Yurubcheno-Tokhomo hydrocarbon accumulation belt (He et al. 2008) 


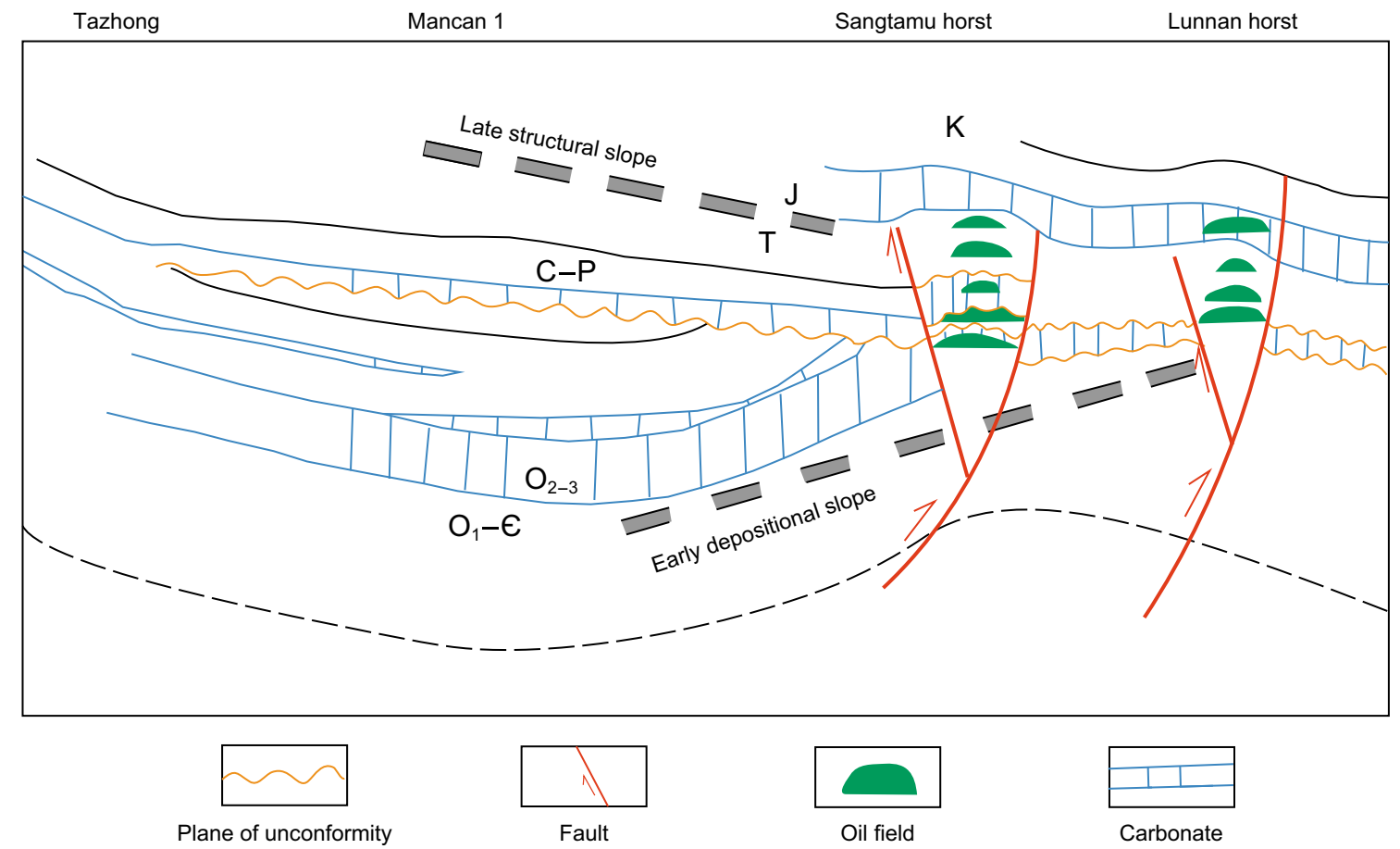

Fig. 10 Correlation between the depositional-structural slope and hydrocarbon distribution in the Tarim Basin (Jin 2012)

slope zones in the basins are often the most weathered and eroded areas during tectonic uplifts and are therefore favorable areas for the development of weathering crust karst reservoirs. When oil and gas are adequate and regional cap rocks are of high quality, paleo-uplifts and slope zones are favorable for oil and gas enrichment. For example, the Akekule area in the North Uplift of the Tarim Basin, where the Tahe Oilfield located, is a long-term inherited paleo-uplift resulting from an intracratonic deformation and always the target area of oil and gas migrations. Especially, in the Himalayan period, Ordovician source rocks in the slope and depression continually generated hydrocarbons, and oil and gas migrated to the Middle and Lower Ordovician paleo-karst reservoirs in both sides of the paleo-uplift and both slopes (mainly along the unconformities) to form giant oil and gas fields in the gathering area (Xiang et al. 2010; Jin 2012) (Fig. 10).

\section{Exploration and research prospects}

\subsection{Exploration prospects in China}

Among the factors that controlled the formation and distribution of the PLP giant oil and gas fields, the size and hydrocarbon generation potential of the hydrocarbon source rocks determines the quantity of hydrocarbon generated in petroliferous basins; the sealing ability of regional cap rocks after oil and gas accumulation and the ability to maintain the sealing ability determine the amount of oil and gas accumulation. Therefore, the effective development of source rocks and cap rocks facilitates the development of giant oil and gas fields, where hydrocarbon is controlled by source and cap rocks. Paleo-uplifts and slopes are favorable tectonic belt structures for the largescale accumulation of oil and gas; specifically, these structures control hydrocarbon accumulation. The development of high-quality reservoirs determines the specific sites for oil and gas reservoirs and also controls the reservoirs. Therefore, by analyzing the controlling factors at these three levels, it is possible to make a meaningful prediction for favorable areas in PLP oil and gas exploration.

There are abundant oil and gas resources and broad exploration prospects in the Tarim, Sichuan, and Ordos basins, where the marine carbonate strata are well developed. The prospective oil and gas resources of the Tarim Basin are $229 \times 10^{8} \mathrm{t}$; the marine oil and gas resources in the Sichuan Basin are $6.24 \times 10^{12} \mathrm{~m}^{3}$; and the total resources of oil and gas in the Ordos Basin are $195 \times 10^{8} \mathrm{t}$ oil equivalent, with the Lower Paleozoic natural gas resource being $1.62 \times 10^{12} \mathrm{~m}^{3}$ and the upper Paleozoic natural gas resource being $9.5 \times 10^{12} \mathrm{~m}^{3}$. ProterozoicPaleozoic oil and gas exploration prospects are mainly focused in the Tarim Basin, the Sichuan Basin and its adjacent areas, and the Ordos Basin. Cambrian-Ordovician hydrocarbon source rocks have developed throughout the Tarim Basin. The paleo-uplift and slope belt areas are gas 
and oil enrichment zones. The Cambrian subsalt uplift and slope are particularly favorable positions for exploring for giant oil and gas fields. In the Sichuan Basin, natural gas has accumulated in long-term developed paleo-uplifts and their surrounding areas, forming a natural gas gathering area from the Leshan to Longnüsi paleo-uplift, and the Luzhou to Kaijiang paleo-uplift. These paleo-uplifts and slopes are conducive to natural gas accumulation and are priority areas for large gas field exploration. The paleouplifts in the Ordos Basin controlled Paleozoic sedimentary facies and weathering crust zonation, where the Lower Paleozoic natural gas distribution is correlated to the positive ancient topography in the early Paleozoic uplifts and their gentle slope zone. These sedimentary facies and weathering crust zones are mostly enriched zones for natural gas (Cai et al. 2008; Jin 2010, 2012).

\subsection{Research prospects}

\subsubsection{Multiple source rock discrimination}

In many old marine basins, multiple source rocks have developed. These rocks are old, with a high thermal evolution extent, and have experienced multiple hydrocarbon generations and expulsions. Therefore, there are mixed sources for oil and gas, making it difficult to identify the source. Thus, the sources of oil and gas in some giant fields are still controversial. For example, it is unclear whether the Jingbian gas field of the Ordos Basin contains oilformed gas from Ordovician shales and carbonate rocks or coal-formed gas from the Carboniferous-Permian coal measure strata (Chen 1994, 2002; Dai et al. 2005b; Huang et al. 1996; Wang et al. 2009b; Chen et al. 2011; Liu et al. 2012b) and whether the Lower Paleozoic oil and gas in the Tarim Basin are mainly from the Cambrian or Ordovician strata (Liang et al. 2000; Li et al. 2010; Zhang et al. 2012; Tian et al. 2012a, b). Because of the lack of widely recognized key geochemical samples, the main hydrocarbon source in the Tarim Basin will be debated for a long time, which will affect accurate spatial and temporal localization of the hydrocarbon source rock and hydrocarbon supply zone (Jin 2014). Therefore, it is imperative to define the multiple sources of Proterozoic-Paleozoic oil and gas for further petroleum exploration.

\subsubsection{Dynamic cap rock evolution}

In cap rock research, most studies have concentrated on lithologic characterization, static sealing performance and mechanisms, or thickness and spatial distribution. Little has been published on dynamic cap rock evolution. Assessments of the sealing ability of the cover layer during the buried stage mainly correlate the porosity with the breakthrough pressure, only considering the effect of compaction on porosity. To consider only the rupture of rock caused by the change of formation, pressure in the uplift stage does not enable an accurate assessment of the sealing ability. For mechanistic studies on the microscopic sealing of different lithology covers, previous work has been conducted mostly on mudstone, with little attention to gypsum and dense carbonate rocks. For practical applications, more studies are required to investigate the relationships between different cover layers (regional cap rocks and direct cap rocks) and the distribution of oil and gas (Jin 2014).

\subsubsection{Identification of a tectonic hinge zone}

Uplifts and slopes are favorable places for oil and gas accumulation in old Proterozoic-Paleozoic layers. Over geological history, sedimentary depressions, slopes, and uplifts may have migrated or converted between depression and uplift in a "seesaw" movement, where the fulcrums are linearly distributed in the plane, forming a hinge zone for tectonic activity. For the migration and the preservation of oil and gas, or the formation and reformation of the highquality carbonate reservoirs, the hinge structure is highly favorable (Jin 2012). At present, the spatial distribution of a hinge zone is estimated mainly through the calculation of denudation quantity and reconstruction of the paleo-structure, and qualitatively used to define its relationship with oil and gas accumulation (Li et al. 2009; Wang et al. 2011; 2012; Jin 2012). In the future, more studies are required to classify tectonic hinge zones and recognize and characterize them quantitatively. This would require investigating the formation, evolution, and spatial distribution of different structural hinge belts. Furthermore, the control of structural hinge belts on various reservoir-formation factors, such as hydrocarbon sources, reservoirs, migration systems, traps, migration, accumulation, and preservation should be investigated against the backdrop of multistage tectonic change and multistage oil and gas accumulation.

\section{Conclusions}

1. The major hydrocarbon source rocks in the PLP marine carbonate giant oil and gas fields are mainly shales of considerable thickness. The types of organic matter are I-II, with such matter being highly abundant and most of it highly mature to over-mature. The reservoirs are mainly gas, and the reservoir rocks are dominated by dolomite. Karst and reef-shoal reservoirs are the main types with well-developed dissolved pores and cavities, and intercrystalline pores and fractures. These reservoirs are characterized by a high degree of 
heterogeneity. The reservoir depth varies considerably and is somewhat negatively correlated to the porosity. The lithology of the cap rocks is mainly dominated by evaporite and thick shale. The thickness is positively correlated to the oil and gas reserves. The development of high-quality evaporite cap rock is highly favorable for oil and gas preservation.

2. The major source rocks have undergone a long period of burial and thermal evolution and are characterized by early and long periods of hydrocarbon generation. They can be divided into four hydrocarbon generation models: early deep burial followed by continuous subsidence; shallow burial followed by uplifting and then deep burial; deep burial followed by uplifting and then shallow burial; and deep burial followed by continuous uplifting.

3. The oil and gas reservoir types are diverse. Most of them are stratigraphic or structural-lithologic, structural-stratigraphic, or lithographic-stratigraphic complex reservoirs, mainly developed in the paleo-uplifts, slope zones and platform margin reef-shoal bodies in the basins.

4. The main factors that control the formation and distribution of the ancient marine carbonate giant oil and gas fields are large-scale efficient hydrocarbon kitchens, favorable hydrocarbon accumulation zones, large-scale high-quality reservoirs, and large areas of high-quality cap rocks.

5. Based on hydrocarbon control by source and cover, accumulation control by paleo-uplifts and slopes, and reservoir control by high-quality reservoir layers, it is possible to predict favorable areas for PLP oil and gas exploration. The Tarim, Sichuan, and Ordos basins have well-developed marine carbonate strata and have great potential for abundant oil and gas resources.

Acknowledgements This work was sponsored by the National Key Basic Research Program of China (973 Program, 2012CB214806) and the National Natural Science Foundation of China (No. 41372144). We thank Liu Wenhui, Sun Dongsheng, Yin Jinyin, and Sun Naida for their help and insightful suggestions for this research.

Open Access This article is distributed under the terms of the Creative Commons Attribution 4.0 International License (http://crea tivecommons.org/licenses/by/4.0/), which permits unrestricted use, distribution, and reproduction in any medium, provided you give appropriate credit to the original author(s) and the source, provide a link to the Creative Commons license, and indicate if changes were made.

\section{References}

Adams DC, Keller GR. Precambrian basement geology of the Permian Basin region of the west Texas and eastern New
Mexico: a geophysical perspective. AAPG Bull. 1996;80(3):410-31.

Alkindi MH, Richard PD. The main structural styles of the hydrocarbon reservoirs in Oman. Geol Soc Lond Spec Publ. 2014;392(1):409-45. doi:10.1144/SP392.20.

Allen PA. The Huqf Supergroup of Oman: basin development and context for Neoproterozoic glaciation. Earth-Sci Rev. 2007;84(84):139-85. doi:10.1016/j.earscirev.2007.06.005.

Bai GP. Distribution patterns of giant carbonate fields in the world. J Paleogeogr. 2006;8(2):241-50. doi:10.3969/j.issn.1671-1505. 2006.02.010 (in Chinese).

Bai GP, Cao BF. Characteristics and distribution patterns of deep petroleum accumulations in the world. Oil Gas Geol. 2014;35(1):19-25. doi:10.11743/ogg20140103 (in Chinese).

Bai GP, Xu Y. Giant fields retain dominance in reserves growth. Oil Gas J. 2014;112(2):44-51.

Bazhenova TK. Evolution of oil and gas generation in the Earth's history and petroleum prediction in sedimentary basins. Russ Geol Geophys. 2009;50(4):308-19. doi:10.1016/j.rgg.2009.03. 008.

Cai LG, Jin ZJ, Chen KQ, et al. Essential feature and potential of hydrocarbon accumulation in China marine sequences. Oil Gas Geol. 2008;29(5):557-73. doi:10.11743/ogg20080503 (in Chinese).

Catacosinos PA, Daniels PA, Harrison WB III. Structure, stratigraphy and petroleum geology of the Michigan Basin: in interior cratonic basins. AAPG Mem. 1990;51:561-601.

Cercone KR. Thermal history of Michigan basin. AAPG Bull. 1984;68(2):130-6.

Charpentier RR. A summary of petroleum plays and characteristics of the Michigan basin. USGS Open-File Report 87-450R. 1987. pp. 1-33.

Chen AD. Origin and migration of natural gas in Ordovician reservoir in Shan Gan Ning Basin central gas field. Acta Pet Sin. 1994;15(2):1-10. doi:10.7623/syxb199402001 (in Chinese).

Chen AD. Feature of mixed gas in central gas field of Ordos basin. Pet Explor Dev. 2002;29(2):33-8. doi:10.3321/j.issn:1000-0747. 2002.02.008 (in Chinese).

Chen $\mathrm{Q}, \mathrm{Li}$ WH, Hao SL, et al. Carbon isotope evidence for Ordovician marine hydrocarbon source rocks in Ordos Basin, North China. Energy Explor Exploit. 2011;29(3):267-90. doi:10. 1260/0144-5987.29.3.267.

Chen JP, Liang DG, Zhang SC, et al. Evaluation criterion and methods of the hydrocarbon generation potential for China's Paleozoic marine source rocks. Acta Geol Sin. 2012;86(7):1132-42. doi:10.3969/j.issn.0001-5717.2012.07.009 (in Chinese).

Chen JP, Liang DG, Zhang SC, et al. Shale and mudstone: essential source rocks in the proterozoic to paleozoic marine basins in China. Acta Geol Sin. 2013;87(7):905-21 (in Chinese).

Cocks LMR, Torsvik TH. The Palaeozoic geography of Laurentia and western Laurussia: a stable craton with mobile margins. Earth Sci Rev. 2011;106(1-2):1-51. doi:10.1016/j.earscirev.2011.01. 007.

Cocks LMR, Torsvik TH. The dynamic evolution of the Palaeozoic geography of eastern Asia. Earth Sci Rev. 2013;117:40-79. doi:10.1016/j.earscirev.2012.12.001.

Dai JX, Li J, Luo X, et al. Alkane carbon isotopic composition and gas source in giant gas fields of Ordos Basin. Acta Pet Sin. 2005a;26(1):18-26. doi:10.7623/syxb200501004 (in Chinese).

Dai JX, Qin SF, Tao SZ, et al. Developing trends of natural gas industry and the significant progress on natural gas geological theories in China. Nat Gas Geosci. 2005b;16(2):127-42 (in Chinese).

Dakhnova MV, Bazhenova TK, Lebedev VS, et al. Isotopic criteria for predicting the phase composition of hydrocarbons in Riphean 
and Vendian deposits of the Lena-Tunguska petroleum province. Russ Geol Geophys. 2011;52(8):945-53. doi:10.1016/j. rgg.2011.07.015.

Du XD, Zhao QH, Ni GH, et al. Reservoir evaluation and oil-gas distribution of Yurubcheno oil field in Russia. J Jilin Univ. 2009;39(6):968-75. doi:10.3969/j.issn.1671-5888.2009.06.002 (in Chinese).

Du JH, Yang H, Xu CC, et al. Carbonate reservoir forming conditions of East Siberia platform and its inspiration to oil and gas exploration in China. Lithol Reserv. 2013;25(3):1-8. doi:10. 3969/j.issn.1673-8926.2013.03.001 (in Chinese).

$\mathrm{Du} \mathrm{JH}$, Zou CN, Xu CC, et al. Theoretical and technical innovations in strategic discovery of a giant gas field in Cambrian Longwangmiao Formation of central Sichuan paleo-uplift, Sichuan Basin. Pet Explor Dev. 2014;41(3):268-77. doi:10. 11698/PED.2014.03.02 (in Chinese).

Dutton SP, Kim EM, Broadhead RF, et al. Play analysis and leadingedge oil-reservoir development methods in the Permian Basin: increased recovery through advanced technologies. AAPG Bull. 2005;89(5):553-76. doi:10.1306/12070404093.

Fan JS. Characteristics of carbonate reservoirs for oil and gas fields in the world and essential controlling factors for their formation. Earth Sci Front. 2005;12(3):23-30. doi:10.3321/j.issn:10052321.2005.03.004 (in Chinese).

Filbrandt JB, Al-Dhahab S, Al-Habsy A, et al. Kinematic interpretation and structural evolution of North Oman, Block 6, since the Late Cretaceous and implications for timing of hydrocarbon migration into Cretaceous reservoirs. GeoArabia. 2006;11(1):97-140.

Fisher JH, Barratt MW, Droste JB, et al. Michigan Basin, the geology of North America, sedimentary cover-North American Craton, US. Geol Soc Am. 1988;13:361-82.

Frolov SV, Akhmanov GG, Bakay EA, et al. Meso-Neoproterozoic petroleum systems of the Eastern Siberian sedimentary basins. Precambr Res. 2015;259:95-113. doi:10.1016/j.precamres.2014. 11.018.

Gale JFW, Gomez LA. Late opening-mode fractures in karstbrecciated dolostones of the Lower Ordovician Ellenburger Group, west Texas: recognition, characterization, and implications for fluid flow. AAPG Bull. 2007;91(7):1005-23. doi:10. 1306/03130706066.

Gorin GE, Racz LG, Walter MR. Late Precambrian-Cambrian sediments of Huqf Group, Sultanate of Oman. AAPG Bull. 1982;66(12):2609-27.

Gu ZD, Wang ZC, Hu SY, et al. Tectonic settings of global marine carbonate giant fields and exploration significance. Nat Gas Geosci. 2012;23(1):107-17 (in Chinese).

Halbouty MT. Giant oil and gas fields of the decade 1990-1999. AAPG Memoir. 2003;78:1-13.

He DF, Zhao WZ, Lei ZY, et al. Characteristics of composite petroleum systems of superimposed basins in China. Earth Sci Front. 2000;7(3):23-37. doi:10.3321/j.issn:1005-2321.2000.03. 003 (in Chinese).

He DF, Jia CZ, Li DS, et al. Formation and evolution of polycyclic superimposed Tarim Basin. Oil Gas Geol. 2005;26(1):64-77. doi:10.3321/j.issn:0253-9985.2005.01.010 (in Chinese).

He DF, Li DS, Tong XG, et al. Accumulation and distribution of oil and gas controlled by paleo-uplift in poly-history superimposed basin. Acta Pet Sin. 2008;29(4):475-88. doi:10.3321/j.issn:02532697.2008.04.001 (in Chinese).

He DF, Li DS, Zhang GW, et al. Formation and evolution of multicycle superposed Sichuan Basin, China. Chin J Geol. 2011a;46(3):589-606. doi:10.3969/j.issn.0563-5020.2011.03. 001 (in Chinese).
He ZL, Wei XC, Qian YX, et al. Forming mechanism and distribution prediction of quality marine carbonate reservoirs. Oil Gas Geol. 2011b;32(4):489-98. doi:10.11743/ogg20110401 (in Chinese).

He ZL, Jin XH, Wo YJ, et al. Hydrocarbon accumulation characteristics and exploration domains of ultra-deep marine carbonates in China. China Pet Explor. 2016;21(1):3-14 (in Chinese).

Hills JM. Sedimentation, tectonism, and hydrocarbon generation in Delaware Basin, West Texas and southeastern New Mexico. AAPG Bull. 1984;68(3):250-67. doi:10.1306/AD460A08-16F711D7-8645000102C1865D.

Huang DF, Xiong CW, Yang JJ, et al. Source discrimination of natural gas in central giant gas field of Ordos basin. Nat Gas Ind. 1996;41(17):1588-92. doi:10.3321/j.issn:1000-0976.1996.06. 001 (in Chinese).

Husnitdinov RR. Approaches to studies of fractured Riphean reservoirs, Kuyumba oil field. In: 3rd EAGE international GeoBaikal conference 2014-exploration and field development in East Siberia. 2014.

Ijirigho BT, Schreiber JF. Composite classification of fractured and brecciated carbonate rocks-examples from the Ordovician Ellenburger Group, West Texas. J Pet Geol. 1988;11(2):193-204. doi:10.1111/j.1747-5457.1988.tb00813.x.

Jacob H. Disperse solid bitumens as an indicator for migration and maturity in prospecting for oil and gas-A model for NW Germany. Erdol und Kohle. 1985;38:365.

Jarvie DM. Total organic carbon (TOC) analysis. In: Merrill RK, editor. Source migration processes and evaluation techniques. American Association of Petroleum Geologist, Treatise of Petroleum Geology Handbook of Petroleum Geology. 1991. pp. 113-18.

Jia CZ, Wei GQ. Tectonic characteristics and petroleum in Tarim Basin. Chin Sci Bull. 2002;47(S1):1-8. doi:10.3321/j.issn:0023074X.2002.z1.001 (in Chinese).

Jia CZ, He DF, Shi X, et al. Characteristics of China's oil and gas pool formation in latest geological history. Sci China Ser D. 2006;49(9):947-59. doi:10.1007/s11430-006-0947-7.

Jiang ZX, Yang HJ, Li Z, et al. Differences of hydrocarbon enrichment between the upper and the lower structural layers in the Tazhong Paleouplift. Acta Geol Sin. 2010;84(5):1116-27. doi:10.1111/j.1755-6724.2010.00284.x (in Chinese).

Jin ZJ. Particularity of petroleum exploration on marine carbonate strata in China sedimentary basins. Earth Sci Front. 2005;12(3):15-22. doi:10.3321/j.issn:1005-2321.2005.03.003 (in Chinese).

Jin ZJ. Petroliferous features of marine carbonate strata and hydrocarbon resource prospects in China. Front Sci. 2010;4(13):11-23. doi:10.3969/j.issn.1673-8128.2010.01.003 (in Chinese).

Jin ZJ. Formation and accumulation of oil and gas in marine carbonate sequences in Chinese sedimentary basins. Sci China Ser D. 2012;55(3):368-85. doi:10.1007/s11430-011-4264-4.

Jin ZJ. A study on the distribution of oil and gas reservoirs controlled by source-cap rock assemblage in unmodified foreland region of Tarim Basin. Oil Gas Geol. 2014;35(6):763-70. doi:10.11743/ ogg20140603 (in Chinese).

Jin ZJ, Yun JB, Zhou B. Types and characteristics of slope zones in Tarim Basin and their relationship with oil accumulation. Oil Gas Geol. 2009;30(2):127-35. doi:10.11743/ogg20090201 (in Chinese).

Jin ZJ, Liu QY, Qiu NS, et al. Phase states of hydrocarbons in Chinese marine carbonate strata and controlling factors for their formation. Energy Explor Exploit. 2012;30(5):753-73. doi:10. 1260/0144-5987.30.5.753.

Jin ZK, Yu KH, Pan Y, et al. Global distribution of Phanerozoic carbonates and controlling factors. Geoscience. 
2013;27(3):637-43. doi:10.3969/j.issn.1000-8527.2013.03.015 (in Chinese).

Kang YZ. Characteristic and distribution laws of Paleokarst hydrocarbon reservoirs in Palaeozoic carbonate formations in China. Nat Gas Ind. 2008;28(6):1-13. doi:10.3787/j.issn.1000-0976. 2008.06.001 (in Chinese).

Kheraskova TN, Kaplan SA, Galuev VI. Structure of the Siberian platform and its western margin in the Riphean-Early Paleozoic. Geotectonics. 2009;43(2):115-32.

doi:10.1134/ S0016852109020046.

Khudoley AK, Rainbird RH, Stern RA, et al. Sedimentary evolution of the Riphean-Vendian basin of southeastern Siberia. Precambr Res. 2001;111(S1-4):129-63. doi:10.1016/S03019268(01)00159-0.

Klemme HD, Ulmishek GF. Effective petroleum source rocks of the world: stratigraphic distribution and controlling depositional factors. AAPG Bull. 1991;75(12):1809-51. doi:10.1306/ 0C9B2A47-1710-11D7-8645000102C1865D.

Kontorovich AE, Surkov FC, Trofimuk AA. Geology of oil and gas in Siberia platform. Moscow: Nedra; 1981.

Kupecz JA, Land LS. Progressive recrystallization and stabilization of early-stage dolomite: Lower Ordovician Ellenburger Group, West Texas. Dolomites: a volume in honour of Dolomieu. Oxford: Blackwell; 2009. pp. 255-79. doi:10.1002/ 9781444304077.ch15

Lei ZY, Zhang CJ. Study of petroleum system in Ordos Basin. China Pet Explor. 1998;3(1):11-6 (in Chinese).

$\mathrm{Li} \mathrm{B}$. Research on the sequence stratigraphy and lithofacies paleogeography of the early Paleozoic in Ordos Basin. Beijing: China University of Geoscience; 2009. pp. 58-257 (in Chinese).

Li GD, Jin ZJ, Kontorovich AE. An approach to the multi-stage formation of oil-gas pool in Yurubcheno-Tokhomo accumulation zone of Siberian platform. Pet Explor Dev. 2000;27(4):87-91. doi:10.3321/j.issn:1000-0747.2000.04.021 (in Chinese).

Li JJ, Lv XX, Fan QH, et al. The formation of structural pivot and its control on the accumulation and distribution of oil and gas in the superimposed basin: an example from the Tarim Basin. Geotecton et Metallog. 2009;33(1):160-7. doi:10.3969/j.issn.10011552.2009.01.022 (in Chinese).

Li SM, Pang XQ, Yang HJ, et al. Generation, migration and accumulation model for the marine oils in the Tarim Basin. Earth Sci. 2010;35(4):663-73 (in Chinese).

Li CW, Wen L, Tao SZ. Characteristics and enrichment factors of supergiant Lower Cambrian Longwangmiao gas reservoir in Anyue gas field: the oldest and largest single monoblock gas reservoir in China. Energy Explor Exploit. 2015;33(6):827-50. doi:10.1260/0144-5987.33.6.827.

Liang DG, Zhang SC, Zhang BM, et al. Understanding on marine oil generation in China based on Tarim Basin. Earth Sci Front. 2000;7(4):534-47. doi:10.3321/j.issn:1005-2321.2000.04.023 (in Chinese).

Liang XW, Zheng RC, Zhou Y. Sequence patterns and evaluation of source rocks in Cratonic basins: by taking Sinian and Cambrian systems in mid-Yangtze area for example. J Oil Gas Technol. 2006;28(2):17-9 (in Chinese).

Lin CS, Yang HJ, Liu JY, et al. Paleostructural geomorphology of the Paleozoic central uplift belt and its constraint on the development of depositional facies in the Tarim Basin. Sci China Ser D. 2009;39(3):306-16. doi:10.1007/s11430-009-0061-8 (in Chinese)

Liu RB, Tian JC, Wei ZH, et al. Comprehensive research of effective hydrocarbon source rock of lower strata from Sinian to Silurian system in southeast area of Sichuan Province. Nat Gas Geosci. 2006;17(6):824-8. doi:10.3969/j.issn.1672-1926.2006.06.018 (in Chinese).
Liu CY, Zhao HG, Sun YZ. Tectonic background of Ordos Basin and its controlling role for basin evolution and energy mineral deposits. Energy Explor Exploit. 2009a;27(1):15-27. doi:10. 1260/014459809788708219.

Liu SG, Ma YS, Cai XY, et al. Characteristic and accumulation process of the natural gas from Sinian to Lower Paleozoic in Sichuan Basin, China. J Chengdu Univ Technol. 2009b;36(4):345-54. doi:10.3969/j.issn.1671-9727.2009.04.001 (in Chinese).

Liu W, Meng QY, Zhang GY, et al. Geologic characteristics of oil and gas reservoirs in old Lower Paleozoic and Sinian carbonate rocks. Mar Orig Pet Geol. 2010;15(1):15-20. doi:10.3969/j.issn. 1672-9854.2010.01.003.

Liu SG, Li ZW, Sun W, et al. Basic geological features of superimposed basin and hydrocarbon accumulation in Sichuan Basin, China. Chin Sci Bull. 2011;46(1):233-57 (in Chinese).

Liu QY, Jin ZJ, Wang Y, et al. Gas filling pattern in Paleozoic marine carbonate reservoir of Ordos Basin. Acta Pet Sin. 2012a;28(3):847-58 (in Chinese).

Liu WH, Wang J, Teng GE, et al. Multiple hydrocarbon generation of marine strata and its tracer technique in China. Acta Pet Sin. 2012b;33(1):115-25. doi:10.7623/syxb2012S1014 (in Chinese).

Loosveld RJH, Bell A, Terken JJM. The tectonic evolution of interior Oman. GeoArabia. 1996;1(1):28-50.

Lucia FJ. Carbonate reservoir characterization: an integrated approach. New York: Springer; 2007. doi:10.2118/82071-JPT.

Luo P, Zhang J, Liu W, et al. Characteristics of marine carbonate hydrocarbon reservoirs in China. Earth Sci Front. 2008;15(1):36-50. doi:10.3321/j.issn:1005-2321.2008.01.004 (in Chinese).

Lv YF, Fu G, Yu D. Comprehensive evaluation of sealing ability of cap rock in China's large and medium gas fields and their contribution to gas accumulation. Oil Gas Geol. 2005;26(6):742-5. doi:10.11743/ogg20050608 (in Chinese).

Ma YS, Cai XY, Zhao PR. The research status and advances in porosity evolution and diagenesis of deep carbonate reservoir. Earth Sci Front. 2011;18(4):181-92 (in Chinese).

McKee ED, Oriel SS, Myers DA, et al. Paleotectonic investigations of the Permian system in the United States. US Geol Surv Prof Pap. 1967;515:1-261.

Moore $\mathrm{CH}$. Carbonate reservoirs: porosity evolution and diagensis in a sequence stratigraphic framework. NewYork: Elsevier; 2001.

Nicholas CJ, Gold SEP. Ediacaran-Cambrian Sirab Formation of the Al Huqf region, Sultanate of Oman. GeoArabia. 2012;17(1):49-98.

Nikishin AM, Sobornov KO, Prokopiev AV, et al. Tectonic evolution of the Siberian Platform during the Vendian and Phanerozoic. Mosc Univ Geol Bull. 2010;65(1):1-16. doi:10.3103/ S0145875210010011.

Pang XQ, Zhou XY, Yan SH, et al. Research advances and direction of hydrocarbon accumulation in the superimposed basins, China: take the Tarim Basin as an example. Pet Explor Dev. 2012;39(6):649-56 (in Chinese).

Pang XQ, Chen DX, Zhang J, et al. Physical simulation experimental study on mechanism for hydrocarbon accumulation controlled by facies—potential—source coupling. J Palaeogeogr. 2013;5:575-92 (in Chinese).

Pang XQ, Jiang ZX, Huang HD, et al. Formation mechanisms, distribution models and prediction of superimposed, continuous hydrocarbon reservoirs. Acta Pet Sin. 2014;35(5):1-34. doi:10. 7623/syxb201405001.

Pang XQ, Jia CZ, Wang WY. Petroleum geology features and research developments of hydrocarbon accumulation in deep petroliferous basins. Pet Sci. 2015;12:1-53. doi:10.1007/s12182015-0014-0. 
Peng PA, Liu DY, Qin Y, et al. Low limits of organic carbon content in carbonate as oil and gas source rocks. Geochimica. 2008;37(4):415-22. doi:10.3321/j.issn:0379-1726.2008.04.015 (in Chinese).

Peters KE. Guideline of evaluating petroleum source rock using programmed pyrolysis. AAPG Bull. 1986;70(3):318-29. doi:10. 1306/94885688-1704-11D7-8645000102C1865D.

Postnikova IY, Postnikova OV, Tikhomurova GI, et al. Karst model of Riphean natural reservoir of Yurubchen-Tokhom field. Pet Geol. 2002;36(2):149-58.

Qiu NS, Chang J, Zuo YH, et al. Thermal evolution and maturation of Lower Paleozoic source rocks in the Tarim Basin, northwest China. AAPG Bull. 2012;96(5):789-821. doi:10.1306/ 09071111029.

Ritter AL. Evaluating the controls on reservoir heterogeneity of Silurian pinnacle reefs, Michigan Basin. M.S. thesis, Western Michigan University, 2008.

Ross CA. Paleozoic evolution of southern margin of Permian Basin. Geol Soc Am Bull. 1986;97(5):536. doi:10.1130/00167606(1986)97\%3C536:PEOSMO\%3E2.0.CO;2.

Shi CH, Cao J, Bao JP, et al. Source characterization of highly mature pyrobitumens using trace and rare earth element geochemistry: Sinian-Paleozoic paleo-oil reservoirs in South China. Org Geochem. 2015;83-84:77-93. doi:10.1016/j.orggeochem.2015. 03.008.

Sun W, Liu SG, Wang GZ, et al. Characteristic of gas formatted from Paleozoic in Weiyuan area of Sichuan Basin, China. J Chengdu Univ Technol. 2010;37(5):481-9. doi:10.3969/j.issn.1671-9727. 2010.05 .001 (in Chinese).

Tang WL, Zhang WX, Xing J, et al. The Lower Paleozoic gas-bearing system of the Ordos Basin and its exploration direction. Exp Pet Geol. 2000;22(1):28-34. doi:10.3969/j.issn.1001-6112.2000.01. 005 (in Chinese).

Tao GQ, Dong QS, Nie H, et al. Research on hydrocarbon accumulation condition and distributive regulation of Siberian platform, Russia. Glob Geol. 2012;31(1):139-47. doi:10.3969/j. issn.1004-5589.2012.01.017 (in Chinese).

Terken JMJ, Frewin NL. The Dhahaban petroleum system of Oman. AAPG Bull. 2000;84(4):523-44. doi:10.1306/C9EBCE41-173511D7-8645000102C1865D.

Terken JMJ, Frewin NL, Indrelid S. Petroleum systems of Oman: charge timing and risks. AAPG Bull. 2001;85(10):1817-45. doi:10.1306/8626D081-173B-11D7-8645000102C1865D.

Tian YK, Yang CP, Liao ZW, et al. Geochemical quantification of mixed marine oils from Tazhong area of Tarim Basin, NW China. J Pet Sci Eng. 2012a;90-91(4):96-106. doi:10.1016/j. petrol.2012.04.028.

Tian YK, Zhao J, Yang CP, et al. Multiple-sourced features of marine oils in the Tarim Basin, NW China: geochemical evidence from occluded hydrocarbons inside asphaltenes. J Asian Earth Sci. 2012b;54-55(4):174-81. doi:10.1016/j.jseaes.2012.04.010.

Tucker ME, Wright VP. Carbonate sedimentology. Oxford: Blackwell; 1990. doi:10.1002/9781444314175.

Wang TG, Han KY. On Meso-Neoproterozoic primary petroleum resources. Acta Pet Sin. 2011;32:1-7. doi:10.7623/ syxb201101001 (in Chinese).

Wang ZX, Jin ZJ. Petroleum geology characteristics of the Siberian platform and its marginal depressions. Studies series of overseas oil and gas basin-Asian volume. Beijing: China Petrochemical Press; 2007 (in Chinese).

Wang FY, Zhang BM, Zhang SC. Anoxia versus bioproductivity controls on the Cambrian and Ordovician marine source rocks in Tarim Basin, China. AAPG Annual Meeting, 2002.

Wang CG, Wang Y, Xu HZ, et al. Discussion on evolution of source rocks in Lower Paleozoic of Ordos Basin. Acta Pet Sin. 2009a;30(1):38-45. doi:10.7623/syxb200901008 (in Chinese).
Wang ZY, Zhao WZ, Zhang SC, et al. Origin of deep marine gas and oil cracking gas potential of Paleozoic source rocks in Tarim Basin. Acta Sedimentol Sin. 2009b;27(1):153-63 (in Chinese).

Wang WG, Lv XX, Yu L, et al. Structural pivot zone and its oil-gas accumulation conditions in Tarim Basin. Xinjiang Pet Geol. 2011;32(4):333-7 (in Chinese).

Wang ZC, Jiang H, Liu W, et al. Types of tectonic hinge zone and its effect on hydrocarbon accumulation in carbonate reservoirs of cratonic basins in China. Acta Pet Sin. 2012;33(S2):11-20. doi:10.7623/syxb2012S2002 (in Chinese).

Wang ZC, Zhao WZ, Hu SY, et al. Reservoir types and distribution characteristics of large marine carbonate oil and gas fields in China. Oil Gas Geol. 2013a;34(2):153-60. doi:10.11743/ ogg20130202 (in Chinese).

Wang ZM, Su J, Zhu GY, et al. Characteristics and accumulation mechanism of quasi-layered Ordovician carbonate reservoirs in the Tazhong area, Tarim Basin. Energy Explor Exploit. 2013b;31(4):545-68. doi:10.1260/0144-5987.31.4.545.

Wei KS, Xu HD, Ye SF. Sequence stratigraphic analysis of Lower Paleozoic in north Ordos Basin. Oil Gas Geol. 1997;18(2):128-70. doi:10.11743/ogg19970208 (in Chinese).

Wei GQ, Du JH, Xu CC, et al. Characteristics and accumulation modes of large gas reservoirs in Sinian-Cambrian of GaoshitiMoxi region, Sichuan Basin. Acta Pet Sin. 2015a;36(1):1-12. doi:10.7623/syxb201501001.

Wei GQ, Yang W, Du JH, et al. Tectonic features of Gaoshiti-Moxi paleo-uplift and its controls on the formation of a giant gas field, Sichuan Basin, SW China. Pet Explor Dev. 2015b;42(3):257-65 (in Chinese).

Xiang CF, Pang XQ, Yang WQ, et al. Hydrocarbon migration and accumulation along the fault intersection zone: a case study on the reef-flat systems of the No. 1 slope break zone in the Tazhong area, Tarim Basin. Pet Sci. 2010;7(2):211-25. doi:10. 1007/s12182-010-0021-0.

Xiao XM. Organic petrology and its application to the evaluation of oil and gas generation. Adv Earth Sci. 1992;7(2):39-44 (in Chinese).

Xiao ZH, Wang ZM, Jiang RQ, et al. Sequence stratigraphic features of the Cambrian carbonate rocks in the Tarim Basin. Oil Gas Geol. 2011;32(1):1-10. doi:10.11743/ogg20110101 (in Chinese).

Xu XS, Liu BJ, Mou CL, et al. Sedimentary-tectonic transition and source and reservoir rocks in three major marine cratonic petroleum-bearing basins in western China. Geol Bull China. 2004;23(11):1066-73. doi:10.3969/j.issn.1671-2552.2004.11. 003 (in Chinese).

Yang KM, Dorobek SL. The Permian Basin of west Texas and New Mexico: tectonic history of a 'composite' foreland basin and its effects on stratigraphic development. SEPM Spec Publ. 1995;52:149-74. doi:10.2110/pec.95.52.0149.

Yang H, Lin XS, Zhang DF. Main controlling factors of gas pooling in Ordovician marine carbonate reservoirs in the Ordos Basin and advances in gas exploration. Nat Gas Ind. 2013;33(5):1-12. doi:10.3969/j.issn.1674-1722.2014.19.243 (in Chinese).

Yang HJ, Zhu GY, Wang Y, et al. The geological characteristics of reservoirs and major controlling factors of hydrocarbon accumulation in the Ordovician of Tazhong area, Tarim Basin. Energy Explor Exploit. 2014;32(2):345-68. doi:10.1260/01445987.32.2.345.

Yi SW, Du JH, Yang HJ, et al. Controlling factors and exploration idea about reservoir formation of lower Paleozoic, Tarim Basin. China Pet Explor. 2012;3(1):1-8. doi:10.3969/j.issn.1672-7703. 2012.03.001 (in Chinese).

$\mathrm{Yu} \mathrm{KH}$, Jin $\mathrm{ZK}$, Pan $\mathrm{Y}$, et al. Phanerozoic carbonate reservoir characteristics and petroleum resource distribution in the world. Nat Gas Geosci. 2012;23(4):748-55 (in Chinese). 
Zhang SC, Zhu GY. Gas accumulation characteristics and exploration potential of marine sediments in Sichuan Basin. Acta Pet Sin. 2006;27(5):1-8. doi:10.7623/syxb200605001 (in Chinese).

Zhang SC, Liang DG, Zhang DJ. Evaluation criteria for Paleozoic effective hydrocarbon source rocks. Pet Explor Dev. 2002;29(2):8-12. doi:10.3321/j.issn:1000-0747.2002.02.002 (in Chinese).

Zhang SC, Zhang BM, Bian LZ, et al. Development constraints of marine source rocks in China. Earth Sci Front. 2005;12(3):39-48. doi:10.3321/j.issn:1005-2321.2005.03.006 (in Chinese).

Zhang GY, Zhao WZ, Wang HJ, et al. Multicycle tectonic evolution and composite petroleum systems in the Tarim Basin. Oil Gas Geol. 2007a;28(5):653-63. doi:10.11743/ogg20070517 (in Chinese).

Zhang SC, Liang DG, Zhu GY, et al. Geological basis of formation of marine oil gas fields in China. Chin Sci Bull. 2007b;52(S1):19-31. doi:10.3321/j.issn:0023-074x.2007.z1.003 (in Chinese).

Zhang SC, Gao ZY, Li JJ, et al. Identification and distribution of marine hydrocarbon source rocks in the Ordovician and Cambrian of the Tarim Basin. Pet Explor Dev. 2012;39(3):305-14. doi:10.1016/S1876-3804(12)60046-9.

Zhang CL, Pang XQ, Tian SC, et al. Oil-source correlation of paleoreservoir in Ordovician and the gas source of Jingbian gasfield, west Ordos Basin. Nat Gas Geosci. 2014a;25(8):1242-51 (in Chinese).

Zhang NN, He DF, Sun YP, et al. Distribution patterns and controlling factors of giant carbonate rock oil and gas fields worldwide. China Pet Explor. 2014b;19(6):54-65. doi:10.3969/j. issn.1672-7703.2014.06.007 (in Chinese).

Zhao MJ, Zhang SC. Genetic classification of natural gas and conditions of gas reservoir formation in Tarim Basin. China Pet Explor. 2001;6(2):27-31. doi:10.3969/j.issn.1672-7703.2001.02. 006 (in Chinese).

Zhao WZ, Wang ZY, Wang HJ, et al. Cracking conditions of oils existing in different modes of occurrence and forward and backward inference of gas source rock kitchen of oil cracking type. Geol China. 2006;33(5):952-65 (in Chinese).

Zhao JZ, Wang QH, Shi BH, et al. Marine hydrocarbon enrichment rules and palaeouplift-controlling hydrocarbon theory for the Paleozoic Tarim craton basin. Oil Gas Geol. 2007;28(6):703-12. doi:10.11743/ogg20070602 (in Chinese).

Zhao MJ, Wang ZM, Pan WQ, et al. Lower palaeozoic source rocks in Manjiaer sag, Tarim Basin. Pet Explor Dev. 2008;35(4):417-23. doi:10.3321/j.issn:1000-0747.2008.04.004 (in Chinese).

Zhao WZ, Wang ZC, Hu SY, et al. Large-scale hydrocarbon accumulation factors and characteristics of marine carbonate reservoirs in three large onshore cratonic basins in China. Acta Pet Sin. 2012a;33(S2):1-10. doi:10.7623/syxb2012S2001.

Zhao ZY, Guo YR, Wang Y, et al. Study progress in tectonic evolution and paleogeography of Ordos Basin. Special Oil and Gas Reservoirs. 2012b;19(5):15-20. doi:10.3969/j.issn.10066535.2012.05.004 (in Chinese).

Zheng M, Jia CZ, Wang WG, et al. The relationship between tectonic evolution and oil-cracking gas accumulation in late stage for marine superimposed basins. Nat Gas Geosci. 2015;26(2):277-91 (in Chinese).

Zhou XX. The petroleum reservoir forming characteristics of the composite superimposed basin: an example from Tarim Basin. Earth Sci Front. 2000;7(3):39-47 (in Chinese).

Zhou XY. Accumulation mechanism of complicated deep carbonate reservoir in the Tazhong area, Tarim Basin. Energy Explor Exploit. 2013;31(3):429-58. doi:10.1260/0144-5987.31.3.429.

Zhou XB, Li JH, Wang HH, et al. Reconstruction of Cambrian global paleo-plates and paleogeography. Mar Orig Pet Geol. 2014;19(2):1-7. doi:10.3969/j.issn.1672-9854.2014.02.001.

Zhu DY, Hu WX, Zhang XF, et al. Characteristics of burial dissolution in the Ordovician limestone of Tahe Oilfield. Acta Pet Sin. 2007;28(5):57-62. doi:10.7623/syxb200705010 (in Chinese).

Zhu GY, Zhang SC, Zhang B, et al. Reservoir types of marine carbonates and their accumulation model in western and central China. Acta Pet Sin. 2010;31(6):871-8. doi:10.7623/ syxb201006001 (in Chinese).

Zhu WL, Wang ZX, Gong SB, et al. Petroliferous basins in Russia. Beijing: Science Press; 2012. pp. 291-378 (in Chinese).

Zhu WL, Bai GP, Li JS, et al. Petroliferous basins in the Middle East. Beijing: Science Press; 2014. pp. 281-320 (in Chinese).

Zhu GY, Wang TS, Xie ZY, et al. Giant gas discovery in the Precambrian deeply buried reservoirs in the Sichuan Basin, China: implications for gas exploration in old cratonic basins. Precambrian Res. 2015;262:45-66. doi:10.1016/j.precamres. 2015.02.023.

Zou $\mathrm{CN}, \mathrm{Du} \mathrm{JH}, \mathrm{Xu} \mathrm{CC}$, et al. Formation, distribution, resource potential and discovery of the Sinian - Cambrian giant gas field, Sichuan Basin, SW China. Pet Explor Dev. 2014a;41(3):278-93. doi:10.11698/PED.2014.03.03 (in Chinese).

Zou CN, Wei GQ, Xu CC, et al. Geochemistry of the SinianCambrian gas system in the Sichuan Basin, China. Org Geochem. 2014b;74:13-21. doi:10.1016/j.orggeochem.2014.03. 004.

Zou CN, Yang Z, Dong DZ, et al. The characteristics and significance of conventional and unconventional Sinian-Silurian gas systems in the Sichuan Basin, Central China. Mar Pet Geol. 2015;64(19):386-402. doi:10.1016/j.marpetgeo.2015.03.005. 